\title{
Experimental and theoretical characterization of ordered MAX phases Mo2TiAlC2 and Mo2Ti2AIC3
}

Babak Anasori, Martin Dahlqvist, Joseph Halim, Eun Ju Moon, Jun Lu, Brian C. Hosler, Elad N. Caspi, Steven J. May, Lars Hultman, Per Eklund, Johanna Rosén and Michel W. Barsoum

\section{Linköping University Post Print}

\section{Tweet}

N.B.: When citing this work, cite the original article.

Original Publication:

Babak Anasori, Martin Dahlqvist, Joseph Halim, Eun Ju Moon, Jun Lu, Brian C. Hosler, Elad N. Caspi, Steven J. May, Lars Hultman, Per Eklund, Johanna Rosén and Michel W. Barsoum, Experimental and theoretical characterization of ordered MAX phases Mo2TiAlC2 and Mo2Ti2AlC3, 2015, Journal of Applied Physics, (118), 9, 094304.

http://dx.doi.org/10.1063/1.4929640

Copyright: American Institute of Physics (AIP)

http://www.aip.org/

Postprint available at: Linköping University Electronic Press http://urn.kb.se/resolve?urn=urn:nbn:se:liu:diva-121746 


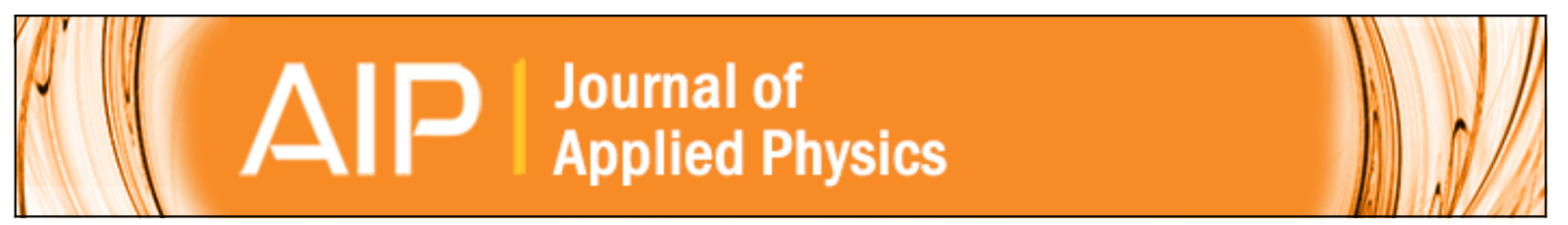

\section{Experimental and theoretical characterization of ordered MAX phases Mo2TiAIC2 and Mo2Ti2AIC3}

Babak Anasori, Martin Dahlqvist, Joseph Halim, Eun Ju Moon, Jun Lu, Brian C. Hosler, El'ad N. Caspi, Steven J. May, Lars Hultman, Per Eklund, Johanna Rosén, and Michel W. Barsoum

Citation: Journal of Applied Physics 118, 094304 (2015); doi: 10.1063/1.4929640

View online: http://dx.doi.org/10.1063/1.4929640

View Table of Contents: http://scitation.aip.org/content/aip/journal/jap/118/9?ver=pdfcov

Published by the AIP Publishing

\section{Articles you may be interested in}

High-temperature neutron diffraction and first-principles study of temperature-dependent crystal structures and atomic vibrations in Ti3AlC2, Ti2AIC, and Ti5Al2C3

J. Appl. Phys. 113, 183519 (2013); 10.1063/1.4803700

Electrical transport and magnetism in Mo-substituted R $2 \mathrm{Ti} 3 \mathrm{Ge} 4(\mathrm{R}=\mathrm{Tb}, \mathrm{Er})$ compounds

J. Appl. Phys. 105, 07 A914 (2009); 10.1063/1.3065977

On the structure of the B 2 phase in Ti-Al-Mo alloys

J. Appl. Phys. 103, 103519 (2008); 10.1063/1.2931004

Factors affecting the laser bending of Ti-6Al-2Sn-4Zr-2Mo

J. Laser Appl. 12, 149 (2000); 10.2351/1.521926

High-coercivity Sm 2 (Fe,Al,Mo) 17 C 1.5 ribbons with addition of Mo

J. Appl. Phys. 83, 5585 (1998); 10.1063/1.367398

\section{AIP $\left.\right|_{\text {APL Photonics }}$}

APL Photonics is pleased to announce Benjamin Eggleton as its Editor-in-Chief

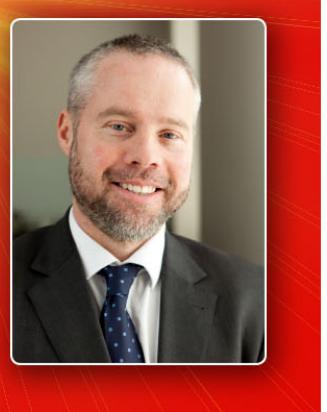




\title{
Experimental and theoretical characterization of ordered MAX phases $\mathrm{Mo}_{2} \mathrm{TiAlC}_{2}$ and $\mathrm{Mo}_{2} \mathrm{Ti}_{2} \mathrm{AlC}_{3}$
}

\author{
Babak Anasori, ${ }^{1,2}$ Martin Dahlqvist, ${ }^{3}$ Joseph Halim,,${ }^{1,3}$ Eun Ju Moon, ${ }^{1}$ Jun Lu, ${ }^{3}$ \\ Brian C. Hosler, ${ }^{1}$ El'ad N. Caspi, ${ }^{1,4}$ Steven J. May, ${ }^{1}$ Lars Hultman, ${ }^{3}$ Per Eklund, ${ }^{3}$ \\ Johanna Rosén, ${ }^{3}$ and Michel W. Barsoum ${ }^{1, a)}$ \\ ${ }^{1}$ Department of Materials Science and Engineering, Drexel University, Philadelphia, Pennsylvania 19104, \\ USA \\ ${ }^{2}$ A.J. Drexel Nanomaterials Institute, Drexel University, Philadelphia, Pennsylvania 19104, USA \\ ${ }^{3}$ Thin Film Physics Division, Department of Physics, Chemistry and Biology (IFM), Linköping University, \\ SE-581 83 Linköping, Sweden \\ ${ }^{4}$ Physics Department, Nuclear Research Centre - Negev, PO Box 9001, 84190 Beer-Sheva, Israel
}

(Received 11 June 2015; accepted 16 August 2015; published online 3 September 2015)

\begin{abstract}
Herein, we report on the phase stabilities and crystal structures of two newly discovered ordered, quaternary MAX phases- $\mathrm{Mo}_{2} \mathrm{TiAlC}_{2}$ and $\mathrm{Mo}_{2} \mathrm{Ti}_{2} \mathrm{AlC}_{3}$ - synthesized by mixing and heating different elemental powder mixtures of mMo:(3-m)Ti:1.1Al:2C with $1.5 \leq \mathrm{m} \leq 2.2$ and $2 \mathrm{Mo}$ : 2Ti:1.1Al:2.7C to $1600{ }^{\circ} \mathrm{C}$ for $4 \mathrm{~h}$ under Ar flow. In general, for $\mathrm{m} \geq 2$ an ordered 312 phase, $\left(\mathrm{Mo}_{2} \mathrm{Ti}\right) \mathrm{AlC}_{2}$, was the majority phase; for $\mathrm{m}<2$, an ordered 413 phase $\left(\mathrm{Mo}_{2} \mathrm{Ti}_{2}\right) \mathrm{AlC}_{3}$, was the major product. The actual chemistries determined from X-ray photoelectron spectroscopy (XPS) are $\mathrm{Mo}_{2} \mathrm{TiAlC}_{1.7}$ and $\mathrm{Mo}_{2} \mathrm{Ti}_{1.9} \mathrm{Al}_{0.9} \mathrm{C}_{2.5}$, respectively. High resolution scanning transmission microscopy, XPS and Rietveld analysis of powder X-ray diffraction confirmed the general ordered stacking sequence to be Mo-Ti-Mo-Al-Mo-Ti-Mo for $\mathrm{Mo}_{2} \mathrm{TiAlC}_{2}$ and Mo-Ti-Ti-Mo-Al-Mo-Ti-TiMo for $\mathrm{Mo}_{2} \mathrm{Ti}_{2} \mathrm{AlC}_{3}$, with the carbon atoms occupying the octahedral sites between the transition metal layers. Consistent with the experimental results, the theoretical calculations clearly show that $\mathrm{M}$ layer ordering is mostly driven by the high penalty paid in energy by having the Mo atoms surrounded by $C$ in a face-centered configuration, i.e., in the center of the $M_{n+1} X_{n}$ blocks. At $331 \mathrm{GPa}$ and $367 \mathrm{GPa}$, respectively, the Young's moduli of the ordered $\mathrm{Mo}_{2} \mathrm{TiAlC}_{2}$ and $\mathrm{Mo}_{2} \mathrm{Ti}_{2} \mathrm{AlC}_{3}$ are predicted to be higher than those calculated for their ternary end members. Like most other MAX phases, because of the high density of states at the Fermi level, the resistivity measurement over 300 to $10 \mathrm{~K}$ for both phases showed metallic behavior. (C) 2015 AIP Publishing LLC.

[http://dx.doi.org/10.1063/1.4929640]
\end{abstract}

\section{INTRODUCTION}

The MAX phases are a large family of hexagonal, ternary, carbides and nitrides with a general formula $M_{n+1} A X_{n}$, where $\mathrm{n}=1,2,3$, etc., $\mathrm{M}$ is an early transition metal (Sc, Ti, $\mathrm{Zr}, \mathrm{Hf}, \mathrm{V}, \mathrm{Nb}, \mathrm{Ta}, \mathrm{Cr}, \mathrm{Mo}$, etc.), $\mathrm{A}$ is a group 13 to 16 element (Al, Ga, In, Tl, Si, Ge, Sn, Pb, P, As, etc.) and X is carbon and/or nitrogen. ${ }^{1-3}$ Depending on the number of $\mathrm{M}$ layers, the shorthand notation 211,312 , and 413 is typically used, when $\mathrm{n}$ is 1,2 , or 3 , respectively. These phases combine some of the best attributes of metals and ceramics, which can be ascribed to their thermodynamically stable nanolaminated layered structure and the metal-like nature of their bonding. Like metals, they are electrically and thermally conductive, most readily machinable, ${ }^{4,5}$ not susceptible to thermal shock, plastic at high temperatures, and exceptionally damage tolerant. ${ }^{6}$ Like ceramics, some of them are elastically rigid (Young's moduli > $300 \mathrm{GPa}$ ), lightweight $\left(\approx 4 \mathrm{~g} / \mathrm{cm}^{3}\right)$, and maintain their strengths to high temperatures. $^{1,3}$

Among the more than $70+$ different MAX phases that have been synthesized to date, some Al-containing ones,

\footnotetext{
a) Author to whom correspondence should be address. Electronic mail: barsoumw@drexel.edu
}

notably $\mathrm{Ti}_{2} \mathrm{AlC}$, have attracted the most attention due to their exceptional oxidation resistance. ${ }^{7-9}$ Crack self-healing characteristics have also been reported during the oxidation of $\mathrm{Ti}_{2} \mathrm{AlC}$ and $\mathrm{Ti}_{3} \mathrm{AlC}_{2}{ }^{10-12}$

More recently, we showed that by selectively etching the Al from Al-containing MAX phases, it is possible to synthesize a new family of two-dimensional (2D) materials, which we labeled MXenes. The latter have been so-called to emphasize the selective etching of the A-element from the parent MAX phase. The suffix ene was added to indicate the similarities of the resulting $2 \mathrm{D}$ materials to graphene. We note in passing that in contrast to hydrophobic graphene, MXenes are hydrophilic and conductive. ${ }^{13,14}$ In some cases, after etching of the $\mathrm{Al}$, the resulting material behaves as a clay with capacities of the order of $1000 \mathrm{~F} / \mathrm{cm}^{3} .^{15}$

To date, $\mathrm{Al}$ is the only A-element that has been successfully etched from the MAX phases to produce MXenes. ${ }^{13}$ It follows that MXene synthesis has been limited to Alcontaining MAX phases. Although there are 10 different $\mathrm{M}$ elements and about 12 A elements in the MAX phase family, not all $\mathrm{M}$ elements bond to all A elements. For example, Al only bonds to $\mathrm{Ti}, \mathrm{V}, \mathrm{Cr}, \mathrm{Nb}$, and Ta. Moreover, some M elements bond to a smaller subset of A elements. We note in passing that the only Mo-containing MAX phase known to date is $\mathrm{Mo}_{2} \mathrm{GaC}^{16-18}$ Very recently, a closely related phase, 
$\mathrm{Mo}_{2} \mathrm{Ga}_{2} \mathrm{C}$, with two Ga layers instead of one, has been discovered. ${ }^{19}$ When solid solutions are taken into account, the situation is not very different. For instance, Al-containing $\mathrm{Ti} / \mathrm{V}$ and $\mathrm{Ti} / \mathrm{Nb}$ solid solutions exist, ${ }^{20}$ but these do not add any new elements to those already known to bond to $\mathrm{Al}$. There are few exceptions, however, wherein a solid solution contains a $\mathrm{M}$ element, that do not generally bond to $\mathrm{Al}$, such as $\mathrm{Zr}$ in $\left(\mathrm{Nb}_{0.8}, \mathrm{Zr}_{0.2}\right)_{2} \mathrm{AlC},{ }^{20}$ and $\left(\mathrm{Nb}_{0.6}, \mathrm{Zr}_{0.4}\right)_{2} \mathrm{AlC},{ }^{21}$ or $\mathrm{Mn}$ in $\left(\mathrm{Cr}_{\mathrm{x}}, \mathrm{Mn}_{1-\mathrm{x}}\right)_{2} \mathrm{AlC} .^{22,23}$ In all these examples, however, the mole fraction of the non-Al bonding $\mathrm{M}$ element is less that 0.5 of the total M-content.

A recent discovery in the MAX phase field is the existence of $\left(\mathrm{M}^{\prime}, \mathrm{M}^{\prime \prime}\right)_{\mathrm{n}+1} \mathrm{AlC}_{\mathrm{n}}$ ordered phases, in which two $\mathrm{M}^{\prime}$ layers sandwich one or two $\mathrm{M}^{\prime \prime}$ layers. Recently, two research groups reported that the transition metal layers in $\mathrm{Cr}_{2} \mathrm{TiAlC}_{2}$ and $\mathrm{V}_{2} \mathrm{CrAlC}_{2}$ phases were, for the most part, ordered. ${ }^{24,25}$ Spurred by this work, we very recently reported the discovery of a new Mo-containing ordered phase-isostructural with $\mathrm{Ti}_{3} \mathrm{SiC}_{2}{ }^{4,26}-\mathrm{Mo}_{2} \mathrm{TiAlC}_{2} .{ }^{27}$ In this phase, the $\mathrm{Ti}$ atoms are sandwiched between two Mo-layers that, in turn, are adjacent to the Al planes resulting in a Mo-Ti-Mo-Al-Mo-Ti-Mo stacking order. The $\mathrm{C}$-atoms retain their positions in the octahedral sites between the $\mathrm{M}$ layers.

The discovery of $\mathrm{Mo}_{2} \mathrm{TiAlC}_{2}$ is important for three reasons: (i) it is the first MAX phase in which Mo layers are directly bonded to $\mathrm{Al}$ ones; (ii) it is only the third report of a double transition metal ordered MAX phase; and (iii) probably most importantly, it now allows us to fabricate and characterize Mo-based MXenes for the first time. ${ }^{28}$

The major goal of this study is to better understand the crystal structures and phase stabilities of $\mathrm{Mo}_{2} \mathrm{TiAlC}_{2}$ and $\mathrm{Mo}_{2} \mathrm{Ti}_{2} \mathrm{AlC}_{3}$. The latter is a 413 phase that has just been discovered. ${ }^{28}$ For brevity's sake, the notations $\mathrm{Mo}_{2} \mathrm{TiAlC}_{2}$ and $\mathrm{Mo}_{2} \mathrm{Ti}_{2} \mathrm{AlC}_{3}$ will be used. However, as shown below, the Mo:Ti ratio can deviate substantially from the nominal 2:1 or $2: 2$. This study is divided into two parts. In the first, we explore the phase stabilities of these new phases in general, and the effects of different Mo-Ti ratios, in particular. The temperature dependencies of the resistivities of the two phases are also presented. In the second part, the experimental results are bolstered by density functional theory, DFT, calculations of the different compositions synthesized. These calculations leave little doubt that the ordered phases are more stable than their disordered counterparts.

\section{METHODS}

\section{A. Materials and processing}

Elemental powders of Mo, Ti, Al, and graphite (all from Alfa Aesar, Ward Hill, MA), with mesh sizes of -250 , $-325,-325$, and -300 , respectively, were mixed in various molar ratios. The following mMo:(3-m)Ti:1.1Al:2C compositions, where $\mathrm{m}=1.5,1.8$. 2, or 2.2 , were synthesized. Like in most synthesis of Al-containing MAX phases, ${ }^{3}$ extra $\mathrm{Al}$ was added to compensate for its evaporation and/or conversion to alumina, $\mathrm{Al}_{2} \mathrm{O}_{3}$, by reaction with $\mathrm{O}$ contamination of starting powders.

$\mathrm{A}\left(\mathrm{Mo}_{2}, \mathrm{Ti}_{2}\right) \mathrm{Al}_{1.1} \mathrm{C}_{2.7}$ composition was also synthesized. In all cases, the powder mixtures were ball milled — using zirconia milling balls in plastic jars-for $18 \mathrm{~h}$. The mixtures were then placed in covered $\mathrm{Al}_{2} \mathrm{O}_{3}$ crucibles that, in turn, were inserted in an $\mathrm{Al}_{2} \mathrm{O}_{3}$ tube furnace. The latter was heated at a rate of $5^{\circ} \mathrm{C} / \mathrm{min}$ to $1600^{\circ} \mathrm{C}$ and held for $4 \mathrm{~h}$ under flowing argon, Ar. After furnace cooling, the slightly sintered porous compacts were milled into a fine powder using a TiN-coated milling bit.

Pressureless sintered samples were fabricated for transport properties measurements. To do so, -325 mesh $\mathrm{Mo}_{2} \mathrm{TiAlC}_{2}$ and $\mathrm{Mo}_{2} \mathrm{Ti}_{2} \mathrm{AlC}_{3}$ powders were pressed to a load corresponding to a stress of $1 \mathrm{GPa}$ at room temperature and the resulting samples were pressureless sintered under Ar flow at $1600^{\circ} \mathrm{C}$ for $4 \mathrm{~h}$. The relative densities of the sintered pellets were measured using Archimedes' principle and found to be $81 \%$ and $84 \%$, for $\mathrm{Mo}_{2} \mathrm{TiAlC}_{2}$ and $\mathrm{Mo}_{2} \mathrm{Ti}_{2} \mathrm{AlC}_{3}$, respectively.

\section{B. Structural and microstructural characterization}

Powder X-ray diffraction (XRD) was carried out on a diffractometer (Rikagu Smartlab, Tokyo, Japan) in the $3^{\circ}-120^{\circ}$ $2 \theta$ range using $\mathrm{Cu}-\mathrm{K} \alpha$ radiation $(40 \mathrm{KV}$ and $44 \mathrm{~mA}$ ). The step size was $0.02^{\circ}$ with a step time of $7 \mathrm{~s}$ using a $10 \times 10 \mathrm{~mm}^{2}$ window slit. Prior to obtaining the XRD patterns, 10 wt. $\%$ silicon, $\mathrm{Si}$, powder was added to all powders. The latter was used as an internal standard to calibrate the diffraction angles and instrumental peak broadening.

The XRD diffractograms were analyzed by the Rietveld refinement method, using the FULLPROF code. ${ }^{29,30}$ Refinement parameters were: five background parameters, scale factors from which relative phase fractions are evaluated, $X$ and $Y$ profile parameters for peak width limited to the major phases, lattice parameters (LPs), isotropic global atomic displacement parameter for the major phases, $\mathrm{Mo} / \mathrm{Ti}$ intermixing, and atomic positions for all phases.

Powders of $\mathrm{Mo}_{2} \mathrm{TiAlC}_{2}$ and $\mathrm{Mo}_{2} \mathrm{Ti}_{2} \mathrm{AlC}_{3}$ were imaged using a scanning electron microscope, SEM, (Zeiss Supra $50 \mathrm{VP}$, Germany) and the compositions of several individual particles were obtained with an energy-dispersive spectroscope (EDS) (Oxford Inca X-Sight, Oxfordshire, UK). High-resolution scanning transmission electron microscope (HRSTEM) micrographs and EDS spectra were obtained on individual $\mathrm{Mo}_{2} \mathrm{TiAlC}_{2}$ and $\mathrm{Mo}_{2} \mathrm{Ti}_{2} \mathrm{AlC}_{3}$ particles using the Linköping double corrected FEI Titan3 60-300 operated at $300 \mathrm{kV}$, equipped with the Super-X EDS system. Selected area electron diffraction (SAED) characterization was performed using a FEI Tecnai G2 TF20 UT instrument equipped with a field emission gun run at a voltage of $200 \mathrm{kV}$ and a point resolution of $0.19 \mathrm{~nm}$. The specimens were prepared by embedding the MAX powder in a Ti grid, reducing the Ti-grid thickness down to $50 \mu \mathrm{m}$ via mechanical polishing and finally $\mathrm{Ar}^{+}$ion milling to reach electron transparency.

$\mathrm{X}$-ray photoelectron spectroscopy (XPS) was used to determine the chemistries of $\mathrm{Mo}_{2} \mathrm{TiAlC}_{2}$ and $\mathrm{Mo}_{2} \mathrm{Ti}_{2} \mathrm{AlC}_{3}$ in powder form. A Physical Electronics VersaProbe 5000 instrument was used employing a $100 \mu \mathrm{m}$ monochromatic Al-K $\alpha$ to irradiate the sample surface. Photoelectrons were collected by a $180^{\circ}$ hemispherical electron energy analyzer. Samples were analyzed at a $45^{\circ}$ angle between the sample surface and the path to the analyzer. Survey spectra were taken at a pass energy of $117.5 \mathrm{eV}$, with a step size of $0.1 \mathrm{eV}$, 
which was used to obtain the elemental analysis of the powders. High-resolution spectra of Mo 3d, Ti 2p, $\mathrm{Al} 2 \mathrm{p}$, and C $1 \mathrm{~s}$ regions were taken at a pass energy of $23.5 \mathrm{eV}$, with a step size of $0.05 \mathrm{eV}$. The spectra were taken after the samples were sputtered with an Ar beam operating at $3.8 \mathrm{kV}$ and $150 \mu \mathrm{A}$ for $1 \mathrm{~h}$. All binding energies were referenced to that of the valence band edge at $0 \mathrm{eV}$.

Peak fitting for the high-resolution spectra was performed using CasaXPS Version 2.3.16 RP 1.6. Prior to the peak fitting, the background contributions were subtracted using a Shirley function. For the Ti $2 \mathrm{p}_{3 / 2}$ and $2 \mathrm{p}_{1 / 2}$, and Mo $3 \mathrm{~d}_{5 / 2} 3 \mathrm{~d}_{3 / 2}$ components, the intensity ratios of the peaks were constrained to be $2: 1$ and 2:3, respectively. The chemical formulas of $\mathrm{Mo}_{2} \mathrm{TiAlC}_{2}$ and $\mathrm{Mo}_{2} \mathrm{Ti}_{2} \mathrm{AlC}_{3}$ was determined by multiplying the total atomic percentage of each element by the fraction of that element which belongs to the MAX compound obtained from the peak fitting of the high-resolution spectra of the region of that element.

\section{Transport properties}

The temperature dependent DC resistivity was measured in a Quantum Design Physical Properties Measurement System in a four-point probe geometry, equipped with a custom-built setup, using a current source (Keithley 6220, Ohio) and nanovoltmeter for measurement of highly conductive samples. All resistivity measurements were carried out while the sintered samples were warmed from $2 \mathrm{~K}$ to $300 \mathrm{~K}$. Silver paint used to make the electrical contacts. Note that the resistivity curves shown in Section IIIE are cropped at $10 \mathrm{~K}$; below this temperature, artifacts most probably originating from the presence of superconducting impurity phases, were observed (see supplementary material).

\section{Computational details}

All first-principles calculations reported here are carried out using the projector augmented wave $(\mathrm{PAW})^{31}$ method as implemented within the Vienna ab-initio simulation package (VASP). ${ }^{32-34}$ We adopted the generalized gradient approximation (GGA) as parameterized by Perdew-Burke-Ernzerhof $(\mathrm{PBE})^{35}$ for treating electron exchange and correlation effects. Wave functions are expanded in a plane-wave basis set, with an energy cutoff of $400 \mathrm{eV}$. For sampling of the Brillouin zone, we used the Monkhorst-Pack scheme. ${ }^{36}$ The calculated total energy for all phases is converged to within $0.1 \mathrm{meV} /$ atom in terms of $k$-point sampling. To minimize the total energy, the unit-cell volumes, $c / a$ ratios (when necessary), and internal parameters were optimized.

Solid solutions on the $M$-sites, full or partial, were modeled using the special quasi-random structure (SQS) method, ${ }^{37,38}$ where an appropriate supercell was chosen based on the criterion to mimic an atomic distribution in a random alloy, i.e., $M$-site correlation functions equal to zero. In this work, supercells consisting of $4 \times 4 \times 1 M_{3} A X_{2}$ and $M_{4} A X_{3}$ unit cells, with a total of 96 and $128 M$-sites, respectively, were considered.

For a phase to be thermodynamically stable, its energy needs to be lower than the energy of any linear combination of all other competing phases in the system. Said otherwise

$$
\Delta H_{c p}=E(M A X)-E(\text { competing phases })<0 .
$$

In order to identify the set of relevant competing phases, for a given compound, we make use of a linear optimization procedure, ${ }^{38,39}$ which has proven successful in confirming the existence of experimentally known MAX phases, as well as predicting existence of new ones. ${ }^{39-44}$

To calculate the elastic properties of the $\left(M^{\prime}, M^{\prime \prime}\right)_{n+1} A l C_{n}$ $(\mathrm{n}=2,3)$ phases, we used the method described by Fast et al. ${ }^{45}$ where five different strains were applied to the hexagonal unit cell in order to attain the five independent elastic constants $C_{11}, C_{12}, C_{13}, C_{33}$, and $C_{44}$. The strain values used to calculate the elastic constants were \pm 0.01 and \pm 0.02 . From the elastic constants, the Voigt bulk $\left(B_{V}\right)$ and shear moduli $\left(G_{V}\right)$ were calculated, assuming

$$
B_{V}=\frac{2}{9}\left(C_{11}+C_{12}+2 C_{13}+C_{33} / 2\right)
$$

and

$$
\begin{aligned}
G_{V}= & 115\left(2 C_{11}+C_{33}-C_{12}-2 C_{13}\right) \\
& +15\left(2 C_{44}+12\left(C_{11}-C_{12}\right)\right) .
\end{aligned}
$$

In addition, the Young's modulus (E), Poisson's ratio $(\nu)$, and shear anisotropy factor $(A)$ were calculated assuming

$$
\begin{gathered}
E=\frac{9 B_{V} G_{V}}{3 B_{V}+G_{V}}, \\
\nu=\frac{3 B_{V}-2 G_{V}}{2\left(3 B_{V}+G_{V}\right)}, \\
A=\frac{4 C_{44}}{C_{11}+C_{33}-2 C_{13}} .
\end{gathered}
$$

\section{RESULTS AND DISCUSSION}

Before detailing the experimental and theoretical results, it is important to point out that the leitmotiv to this work is this: The lowest energy structures, and the ones that are experimentally obtained, are those in which the Mo layers are adjacent to the $\mathrm{Al}$ layers, with the $\mathrm{Ti}-\mathrm{C}$ layers buried in between the former. Said otherwise the lowest energy configurations possess the following stacking sequence:

$$
\mathrm{Al}-\mathrm{Mo}-\mathrm{Ti}_{\mathrm{i}}-\mathrm{Mo}-\mathrm{Al}-\mathrm{Mo}-\mathrm{Ti}_{\mathrm{i}}-\mathrm{Mo}-\mathrm{Al}-,
$$

where $\mathrm{i}$ is 1 for the $\mathrm{Mo}_{2} \mathrm{TiAlC}_{2}$ phase, and 2 for the $\mathrm{Mo}_{2} \mathrm{Ti}_{2} \mathrm{AlC}_{3}$ phase. The $\mathrm{C}$ atoms not listed above are presumed to occupy octahedral sites between the M-elements. The ultimate reason for this state of affairs is the extreme aversion of the Mo atoms to occupy sites in which the Catoms are not directly on top of one another, i.e., where the $\mathrm{C}$-atoms are in an FCC arrangement. In all cases, Rietveld refinement suggests some intermixing (between 0 to 25 at. \%) between the Ti and Mo layers.

\section{A. Effect of different Mo:Ti ratios on the existence of $\left(\mathrm{Mo}, \mathrm{Ti}_{3} \mathrm{AlC}_{2}\right.$ and $\left(\mathrm{Mo}, \mathrm{Ti}_{4}\right)_{4} \mathrm{AlC}_{3}$}

To shed light on the stabilities of the 312 and 413 phases, five different starting compositions, listed in Table I, 
TABLE I. Phase compositions and lattice parameters of the various starting compositions tested herein determined from Rietveld analysis of XRD data. Also, listed are the minor impurity phases and their wt. $\%$ and the $\chi^{2}$ of the Rietveld refinements. The numbers in parentheses are the uncertainties on the last digit.

\begin{tabular}{|c|c|c|c|c|c|c|c|c|}
\hline \multirow[b]{2}{*}{ Starting composition } & & \multicolumn{2}{|c|}{$\mathrm{Mo}_{2} \mathrm{TiAlC}_{2}$} & \multicolumn{2}{|c|}{$\mathrm{Mo}_{2} \mathrm{Ti}_{2} \mathrm{AlC}_{3}$} & \multicolumn{2}{|c|}{ Impurities } & \multirow[b]{2}{*}{$\chi^{2}$} \\
\hline & & wt. \% & Lattice constants $(\AA)$ & wt. \% & Lattice constants $(\AA)$ & & wt. \% & \\
\hline 2.2Mo:0.8Ti: & $1.1 \mathrm{Al}: 2 \mathrm{C}$ & $95(3)$ & $\begin{array}{l}a: 2.99872(4) \\
c: 18.6183(3)\end{array}$ & - & - & $\begin{array}{c}\mathrm{MoC}_{\mathrm{x}}{ }^{\mathrm{a}} \\
\text { Mo }\end{array}$ & $\begin{array}{c}4 \\
<1\end{array}$ & 2.43 \\
\hline 2Mo:Ti: & $1.1 \mathrm{Al}: 2 \mathrm{C}$ & $91(2)$ & $\begin{array}{l}a: 2.99718(3) \\
c: 18.6614(2)\end{array}$ & $9(2)$ & $\begin{array}{l}a: 3.0196(3) \\
c: 23.529(4)\end{array}$ & - & - & 2.7 \\
\hline 1.8Mo:1.2Ti: & $1.1 \mathrm{Al}: 2 \mathrm{C}$ & $11(3)$ & $\begin{array}{l}a: 2.9984(1) \\
c: 18.667(1)\end{array}$ & $89(3)$ & $\begin{array}{l}a: 3.02076(3) \\
c: 23.5479(4)\end{array}$ & Mo & $<0.7$ & 2.6 \\
\hline 1.5Mo:1.5Ti: & $1.1 \mathrm{Al}: 2 \mathrm{C}$ & 0 & - & $93(3)$ & $\begin{array}{l}a: 3.02119(4) \\
c: 23.5461(5)\end{array}$ & $\begin{array}{c}\mathrm{Mo}_{3} \mathrm{Al}_{8} \\
\mathrm{Mo}_{3} \mathrm{Al}\end{array}$ & $\begin{array}{l}4 \\
3\end{array}$ & 1.93 \\
\hline 2Mo:2Ti: & $1.1 \mathrm{Al}: 2.7 \mathrm{C}$ & 0 & - & $93(3)$ & $\begin{array}{l}a: 3.02064(8) \\
c: 23.5431(7)\end{array}$ & $\begin{array}{l}\mathrm{MoC}_{\mathrm{x}}{ }^{\mathrm{a}} \\
\mathrm{Mo}_{3} \mathrm{Al}\end{array}$ & $\begin{array}{l}3 \\
4\end{array}$ & 2.5 \\
\hline
\end{tabular}

${ }^{\mathrm{a}}$ The level of C occupancy cannot be determined from XRD.

were reacted. The XRD patterns of the 5 different starting compositions synthesized herein are shown in Fig. 1. The weight fractions, lattice parameters, and $\chi^{2}$ values determined from Rietveld analysis of these patterns (see Fig. $\mathrm{S} 1)^{46}$ are listed in Table I. It is crucial to note here that the starting compositions were all chosen such that either the $(\mathrm{Mo}, \mathrm{Ti})_{3} \mathrm{AlC}_{2}(312)$ or $(\mathrm{Mo}, \mathrm{Ti})_{4} \mathrm{AlC}_{3}$ (413) phase would be the majority phase obtained, as indeed observed. Note that the 312 phases detected in all the mixtures possessed quite similar lattice parameters (Table I). The same is true of the

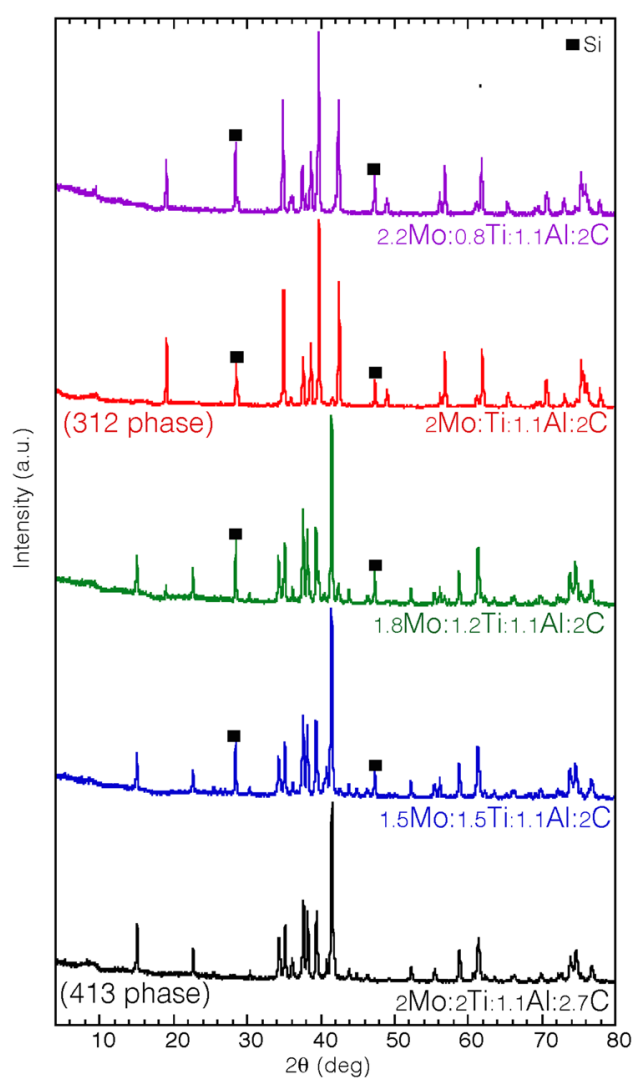

FIG. 1. XRD patterns of 5 different starting compositions-noted below each pattern. Black squares represent Si peaks, added ( $10 \mathrm{wt} . \%)$ as an internal standard before the XRD measurements were taken. Bragg reflections' positions of each phase are shown in Fig. S1. ${ }^{46}$
413 phases (Table I). Schematics of both the 312 and 413 unit cells are shown in Fig. 2.

When the Mo:Ti starting chemistry ratio was 2.2:0.8 (first row in Table I), the majority phase upon reaction was the 312 phase, with $\approx 4$ wt. $\%$ of cubic $\mathrm{MoC}_{\mathrm{x}},{ }^{47}$ and traces of elemental Mo as impurity phases.

Similarly, when the starting Mo:Ti ratio was 2:1 (second row in Table I), the main reaction product (91(2) wt. \%) was again a 312 phase. Here, 9(2) wt. \% of a 413 phase was detected. We note in passing that in our initial report, ${ }^{27}$ the peaks associated with this 413 phase were marked as unknown.

When the starting Mo:Ti ratio was 1.8:1.2 (third row in Table I), and despite the fact that the overall starting chemistry corresponded to a 312 stoichiometric ratio, the final product was 90wt. \% 413 phase. Since the only difference between this mixture and the one above is the Mo:Ti ratio, it

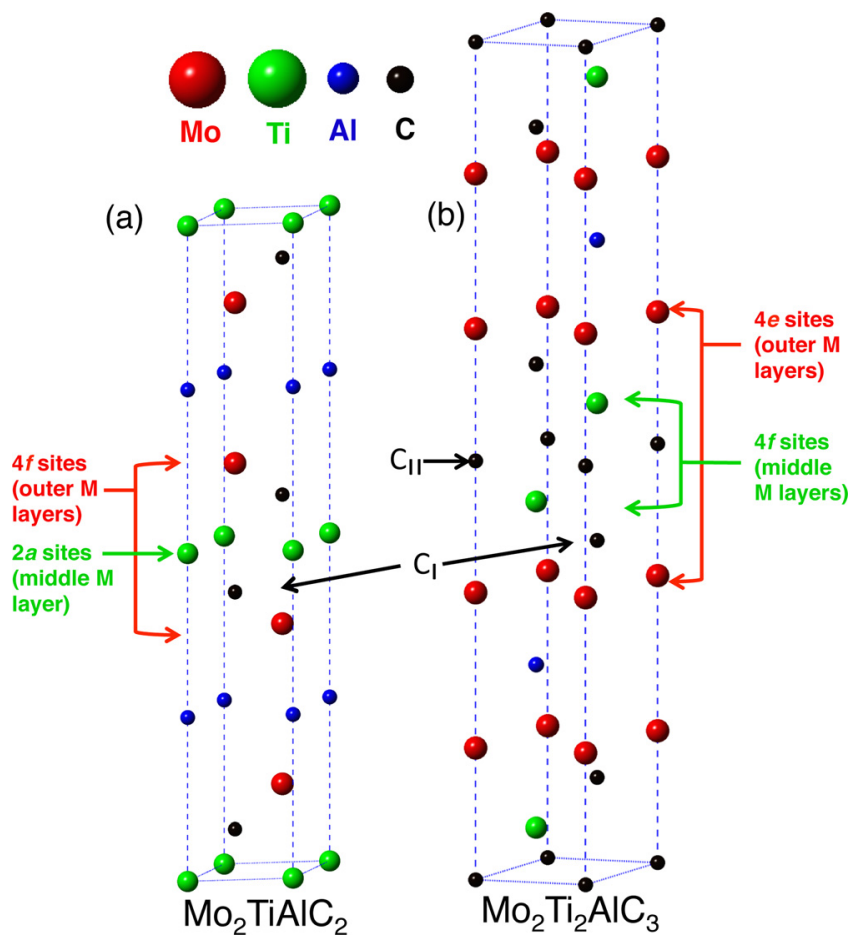

FIG. 2. Unit cells of fully ordered (a) $\mathrm{Mo}_{2} \mathrm{TiAlC}_{2}$ and (b) $\mathrm{Mo}_{2} \mathrm{Ti}_{2} \mathrm{AlC}_{3}$. 
is reasonable to conclude that this ratio is a critical parameter in determining which of these two phases form. For reasons discussed below, reducing the Mo:Ti atomic ratio to below 2 stabilizes the 413 phase and destabilizes the 312 .

To test this idea, a 312 overall starting composition, with a Mo:Ti ratio of 1.5:1.5, was reacted (4th row in Table I). In this case, the final product was mostly the 413 phase and no trace of the 312 phase was detected. The impurity phases were $\mathrm{Mo}_{3} \mathrm{Al}_{8}$ and $\mathrm{Mo}_{3} \mathrm{Al}$. This again signifies that the Mo:Ti ratio is crucial in determining which of the two phases will form.

Note that for this composition, mass balance dictates that

$$
1.5 \mathrm{Mo}+1.5 \mathrm{Ti}+1.1 \mathrm{Al}+2 \mathrm{C}=3 / 4\left(\mathrm{Mo}_{2} \mathrm{Ti}_{2} \mathrm{Al}_{1.46} \mathrm{C}_{2.66}\right) \text {. }
$$

Based on this reaction, it is not surprising that when the starting mixture was $2 \mathrm{Mo}: 2 \mathrm{Ti}: 1.1 \mathrm{Al}: 2.7 \mathrm{C}$, the only MAX phase formed was the 413 phase, with 4 wt. $\% \mathrm{Mo}_{3} \mathrm{Al}$, and $\sim 3$ wt. $\% \mathrm{MoC}_{\mathrm{x}}$ as the impurity phases. Furthermore, C-vacancies are most probably present. ${ }^{48}$

In the rest of this study, we focus only on two starting compositions with the proper stoichiometric ratios that resulted in $\mathrm{Mo}_{2} \mathrm{TiAlC}_{2}$ and $\mathrm{Mo}_{2} \mathrm{Ti}_{2} \mathrm{AlC}_{3}$, viz., $2 \mathrm{Mo}$ :Ti:1.1Al:2C and 2Mo:2Ti:1.1Al:2.7C, respectively.

The atomic occupancies-two $4 f$ and one $2 a$ Wyckoff sites-for the three M layers in $\mathrm{Mo}_{2} \mathrm{TiAlC}_{2}$ (see Fig. 2(a)), and-two $4 e$ and two $4 f$-for the four $M$ layers in $\mathrm{Mo}_{2} \mathrm{Ti}_{2} \mathrm{AlC}_{3}$ (see Fig. 2(b)) were estimated from Rietveld analysis of the XRD patterns are shown in Table II. Based on these results, we conclude that the outer layers in the 312 phase are $75(1)$ at. $\%$ Mo, balance Ti. The middle layers, on the other hand, are 100(1) at.\% Ti. This finding confirms the strong aversion of the Mo atoms to occupy the middle $\mathrm{M}$ layers that are surrounded by $\mathrm{C}$ atoms (in FCC arrangement). In the 413 phase, the outer layers are 77(2) at. \% Mo balance $\mathrm{Ti}$; the inner layers are $86(1)$ at. $\% \mathrm{Ti}$, balance Mo. In other words, these compounds are ordered and their inner M layers are mostly $\mathrm{Ti}$. Given that these powders were reacted at $1600{ }^{\circ} \mathrm{C}$, and that the atomic radii of $\mathrm{Ti}$ and $\mathrm{Mo}$ - at $140 \mathrm{pm}$ and $145 \mathrm{pm}$, respectively-are not too different, implies that the driving force for ordering must be substantial.

It is important to note here that the chemistry predicted from Rietveld analysis is inconsistent-especially for the 312 phase-with other observations (see below), such as

TABLE II. Mo and Ti atomic occupancies of $\mathrm{M}$ sites in the $\mathrm{Mo}_{2} \mathrm{TiAlC}_{2}$ and $\mathrm{Mo}_{2} \mathrm{Ti}_{2} \mathrm{AlC}_{3}$ samples made from the 2Mo:Ti:1.1Al:2C and 2Mo:2Ti:1.1Al:2.7C starting compositions, respectively. The designations outer and inner refer, respectively, to $\mathrm{M}$ atoms adjacent to, and not adjacent to, the $\mathrm{Al}$ layers. The numbers in parentheses are the uncertainties on the last digit.

\begin{tabular}{lcccc}
\hline \hline & \multicolumn{3}{c}{ Occupancies of M sites (at. \%) } \\
\cline { 2 - 5 } & \multicolumn{2}{c}{$\mathrm{Mo}_{2} \mathrm{TiAlC}_{2}$} & & \multicolumn{2}{c}{$\mathrm{Mo}_{2} \mathrm{Ti}_{2} \mathrm{AlC}_{3}$} \\
\cline { 2 - 5 } & $2 a$ (inner) & $4 f$ (outer) & $4 e$ (outer) & $4 f$ (inner) \\
\cline { 4 - 5 } $\mathrm{Ti}$ & $0(1)$ & $75(1)$ & $77(2)$ & $14(1)$ \\
\hline \hline
\end{tabular}

EDS in SEM, XPS, EDS/HRTEM, and most importantly, our nominal starting compositions. The reason for this state of affairs is not understood at this time and more work needs to be carried out to sort out this important discrepancy. Said otherwise, the extent of ordering in the outer layers is, more likely than not, $>75 \%$ Mo for the 312 phase.

The aforementioned caveats notwithstanding, it is crucial to note that regardless of which MAX phase forms (312 or 413), Rietveld analysis is consistent in that the M layers adjacent to the Al-layers are significantly richer in Mo than Ti. In contrast, the inner M layers, which are surrounded by $\mathrm{C}$-atoms, are mostly $\mathrm{Ti}$ (with less intermixing), confirming that the presence of Mo atoms in the middle M-layers destabilizes these phases.

\section{B. HRSTEM of $\mathrm{Mo}_{2} \mathrm{TiAIC}_{2}$ and $\mathrm{Mo}_{2} \mathrm{Ti}_{2} \mathrm{AlC}_{3}$}

Figure 3(a) shows a HRSTEM micrograph of a $\mathrm{Mo}_{2} \mathrm{TiAlC}_{2}$ particle, synthesized starting with a 2:1 Mo:Ti ratio. Every other layer is brighter than its neighbors and can thus be associated with the heavier Mo atoms. The EDS elemental

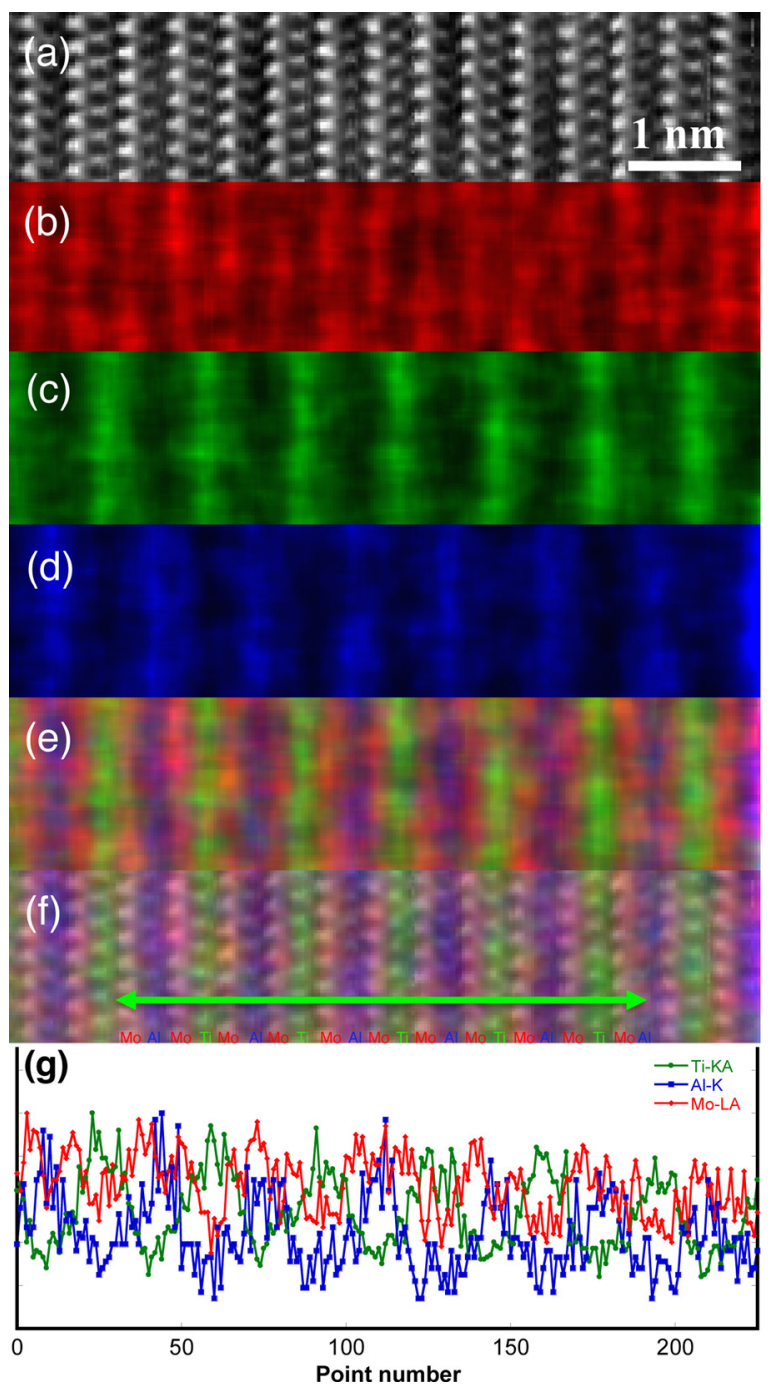

FIG. 3. (a) HRSTEM of $\mathrm{Mo}_{2} \mathrm{TiAlC}_{2}$ along the [11 $\overline{2} 0$ ] zone axis, EDS mapping on (a) for: (b) Mo, (c) Ti, (d) Al. (e) Overlap of (b) and (c). (f) Overlap of (a) and (e) showing the Mo atoms in red, Ti atoms in green and $\mathrm{Al}$ atoms in blue, (g) EDS line scan profile of $\mathrm{Mo}, \mathrm{Ti}$, and $\mathrm{Al}$ over the green arrow shown in $\mathrm{g}$. 
maps and their overlap (Figs. 3(b)-3(d)), in which the Mo, Ti and $\mathrm{Al}$ atoms are shown as red, green, and blue, respectively, confirm this conclusion. When the EDS and HRSTEM images are superimposed (Fig. 3(f)), it is obvious that every green, or $\mathrm{Ti}$, layer is sandwiched between two red, or Mo layers. Figure $3(\mathrm{~g})$ shows an EDS line scan along the [0001] direction on the green arrow shown in Fig. 3(f), where the Mo, Ti, and Al lines have the same coloring as in Fig. 3(e). Here, again, the line scan confirms the proposed ordering sequence.

A HRSTEM image of the $\mathrm{Mo}_{2} \mathrm{Ti}_{2} \mathrm{AlC}_{3}$, sample synthesized starting with Mo:Ti:Al:C atomic ratios of 2:2:1.1:2.7 is shown in Fig. 4(a). Here, two bright atomic layers (Mo) surround two less bright layers (Ti). The 4 Mo-Ti-Ti-Mo layers are, in turn, separated by darker atomic layers that correspond to the Al layers. Similar EDS mapping was done here (Figs. 4(b) to 4(e)) and Fig. 4(f) plots the overlap of Figs. 4(a)-4(e), which clearly shows that two Ti green layers, are sandwiched between two Mo red layers. Interleaved between every 4 M-layers are Al layers, colored blue (Fig. 4(g)).

\section{XPS of $\mathrm{Mo}_{2} \mathrm{TiAlC}_{2}$ and $\mathrm{Mo}_{2} \mathrm{Ti}_{2} \mathrm{AlC}_{3}$}

High-resolution XPS spectra peak fitting of $\mathrm{Mo}_{2} \mathrm{TiAlC}_{2}$ and $\mathrm{Mo}_{2} \mathrm{Ti}_{2} \mathrm{AlC}_{3}$ for Mo 3d, Ti 2p, Al 2p, and C 1s elements

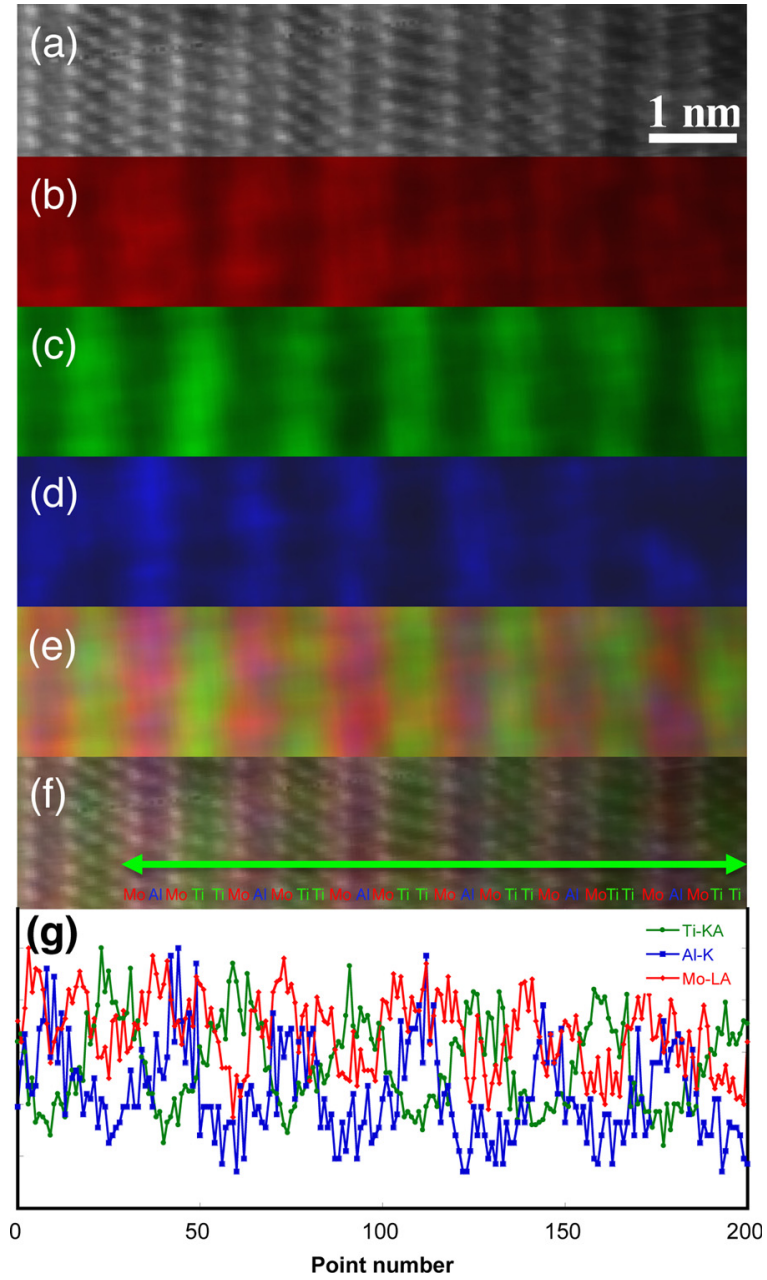

FIG. 4. (a) HRSTEM of $\mathrm{Mo}_{2} \mathrm{Ti}_{2} \mathrm{AlC}_{3}$ along the [1120] zone axis, EDS mapping on (a) for: (b) Mo, (c) Ti, (d) Al. (e) Overlap of (b) and (c). (f) Overlap of (a) and (e) showing the Mo atoms in red, Ti atoms in green and $\mathrm{Al}$ atoms in blue, and (g) EDS line scan profile of Mo, Ti, and Al.

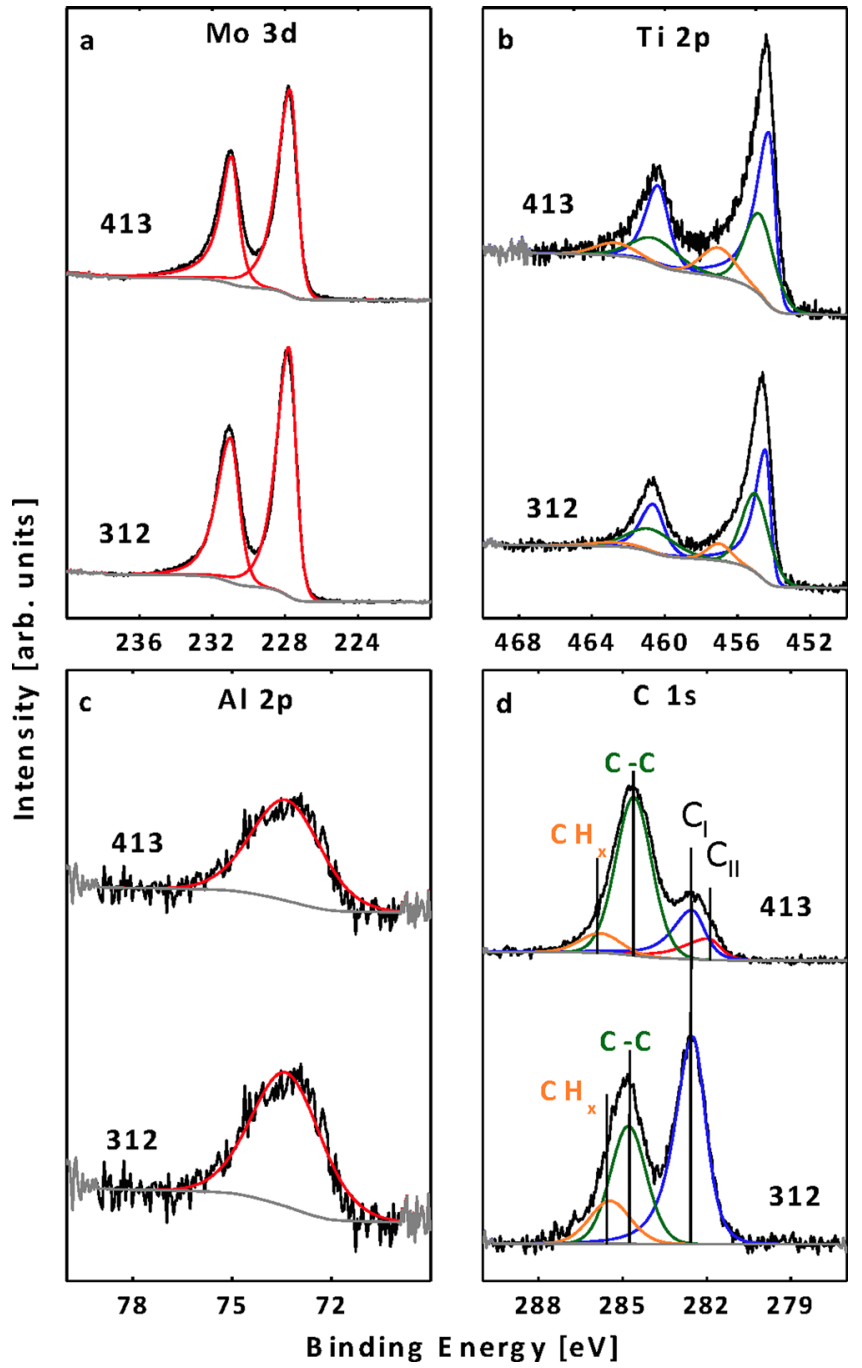

FIG. 5. XPS spectra for elements in $\mathrm{Mo}_{2} \mathrm{Ti}_{2} \mathrm{AlC}_{3}$ (413) and $\mathrm{Mo}_{2} \mathrm{TiAlC}_{2}$ (312) (a) Mo $3 \mathrm{~d}$ (peaks in red correspond to the $3 \mathrm{~d}_{5 / 2}$ and $3 \mathrm{~d}_{3 / 2}$ components of Mo in the 413 and 312 phases), (b) Ti $2 p$ (peaks in blue, green and orange correspond to $2 \mathrm{p}_{3 / 2}$ and $2 \mathrm{p}_{1 / 2}$ components for $\mathrm{Ti}$, $\mathrm{Ti}(+2)$, and $\left.\mathrm{Ti}(+3)\right)$, (c) $\mathrm{Al} 2 \mathrm{p}$ (peaks in red correspond to the $\mathrm{Al}$ component in MAX phase), and (d) $\mathrm{C} 1 \mathrm{~s}$ regions. The blue peaks and red peak fits to the spectra emanate from $\mathrm{C}$ atoms in the 312 and 413 phases. The orange and green emanate from adventitious $\mathrm{C}$ and hydrocarbons.

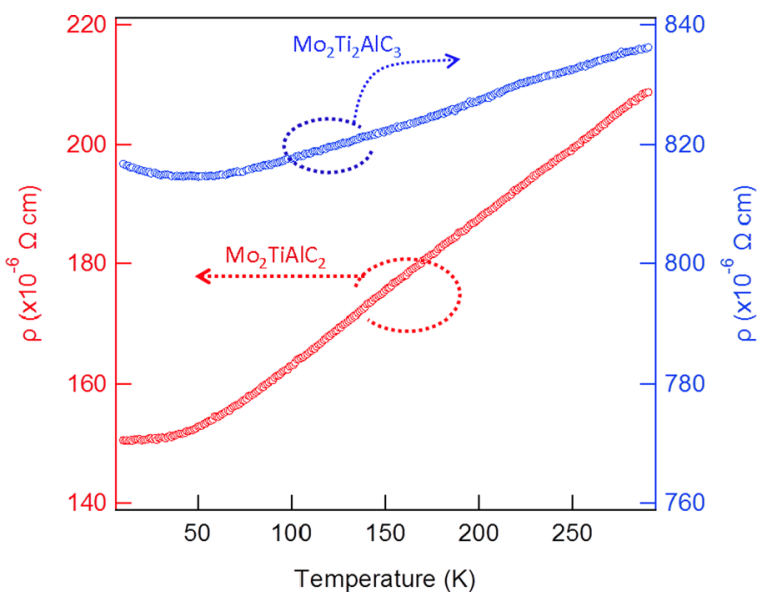

FIG. 6. Temperature dependent resistivity of $\mathrm{Mo}_{2} \mathrm{TiAlC}_{2}$ (red, left-side yaxis) and $\mathrm{Mo}_{2} \mathrm{Ti}_{2} \mathrm{AlC}_{3}$ (blue, right-side $\mathrm{y}$-axis) measured from $10-300 \mathrm{~K}$. 

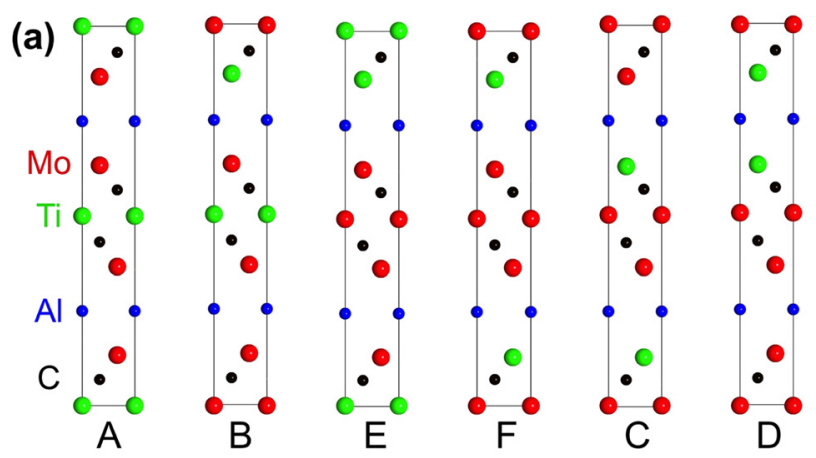

(b)
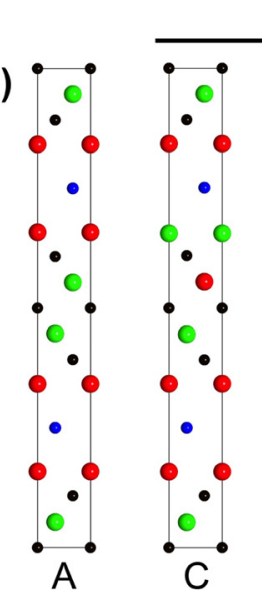

increasing energy
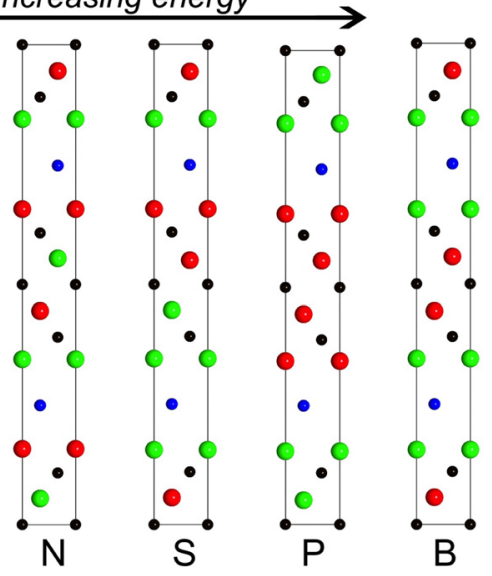

FIG. 7. Ordered structures considered theoretically, (a) all 6 possible ordered $\mathrm{Mo}_{2} \mathrm{TiAlC}_{2}$ unit cells and (b) 6 of $20 \mathrm{Mo}_{2} \mathrm{Ti}_{2} \mathrm{AlC}_{3}$ ordered unit cells (see Tables III and IV). The latter are sorted from most stable on the left, to least stable on the right. The capital letters denote the various unit cells. By far the most stable configuration is the A-type.

are shown in Figs. 5(a)-5(d), respectively. The peak fitting results for the various species in $\mathrm{Mo}_{2} \mathrm{TiAlC}_{2}$ and $\mathrm{Mo}_{2} \mathrm{Ti}_{2} \mathrm{AlC}_{3}$ powders are tabulated in Tables $\mathrm{S} 1$ and $\mathrm{S} 2,{ }^{46}$ respectively.

The high-resolution spectra in the Mo $3 \mathrm{~d}$ region for $\mathrm{Mo}_{2} \mathrm{TiAlC}_{2}$ and $\mathrm{Mo}_{2} \mathrm{Ti}_{2} \mathrm{AlC}_{3}$, (Fig. 5(a)) were fit by 1 species with binding energies, $\mathrm{E}_{\mathrm{B}}$ 's, of $227.8 \mathrm{eV}$ and $227.9 \mathrm{eV}$, respectively (see Tables $\mathrm{S} 1$ and $\mathrm{S} 2){ }^{46}{ }^{4}$ These $\mathrm{E}_{\mathrm{B}}$ 's are almost identical to those in $\mathrm{Mo}_{2} \mathrm{C}(227.8 \mathrm{eV})$ and significantly lower than Mo metal $(228.5 \mathrm{eV}) .{ }^{49}$ The fact that the measured Mo binding energies in both $\mathrm{Mo}_{2} \mathrm{TiAlC}_{2}$ and $\mathrm{Mo}_{2} \mathrm{Ti}_{2} \mathrm{AlC}_{3}$ are almost identical is fully consistent with the fact that the Molayers are on the outside and the Ti layers are on the inside, i.e., ordered.

The Ti $2 p$ region was fit by 3 species corresponding to three $\mathrm{Ti}$ oxidation states species, denoted as $\mathrm{Mo}_{2} \mathrm{TiAlC}_{2}$, $\mathrm{Mo}_{2} \mathrm{Ti}(+2) \mathrm{AlC}_{2}$, and $\mathrm{Mo}_{2} \mathrm{Ti}(+3) \mathrm{AlC}_{2}$ (Fig. 5(b) and Table S1). ${ }^{46}$ The $\mathrm{Ti} \mathrm{E}_{\mathrm{B}}$ 's in $\mathrm{Mo}_{2} \mathrm{TiAlC}_{2}$ is $454.4 \mathrm{eV}$, which is slightly lower than that in $\mathrm{TiC}(454.9-455.1 \mathrm{eV}),{ }^{50-52}$ but higher than Ti metal $(453.9 \mathrm{eV}) .{ }^{53}$ Similarly, the Ti $2 \mathrm{p}$ region of $\mathrm{Mo}_{2} \mathrm{Ti}_{2} \mathrm{AlC}_{3}$ was also fitted by three species denoted as $\mathrm{Mo}_{2} \mathrm{Ti}_{2} \mathrm{AlC}_{3}, \mathrm{Mo}_{2} \mathrm{Ti}_{2}(+2) \mathrm{AlC}_{3}$ and $\mathrm{Mo}_{2} \mathrm{Ti}_{2}(+3) \mathrm{AlC}_{3}$ (Fig. 5 (b) and Table $\mathrm{S}^{46}{ }^{46}$. The $\mathrm{E}_{\mathrm{B}}$ 's of the Ti components in these two Mo-containing MAX phases are almost identical to those reported for $\mathrm{Ti}_{3} \mathrm{AlC}_{2}(454.5 \mathrm{eV}){ }^{54}$ This result is again consistent with the conclusion that the $\mathrm{Ti}$ and Mo atoms are ordered in separate layers in these structures.

The Al 2p regions for the 312 and 413 (Fig. 5(c)) were fit by single peaks at $73.4 \mathrm{eV}$ and $73.8 \mathrm{eV}$, respectively.
These $\mathrm{E}_{\mathrm{B}}$ 's are higher than those of both elemental $\mathrm{Al}$ and $\mathrm{Ti}-\mathrm{Al}$ alloys (72.3 and 71.5-71.4 eV, respectively). ${ }^{55}$

The $\mathrm{C} 1 \mathrm{~s}$ region for $\mathrm{Mo}_{2} \mathrm{TiAlC}_{2}$ was fit by three peaks (Fig. 5(d)), the first peak, at $282.5 \mathrm{eV}$ was assigned to $\mathrm{C}$ atoms bonded to the outer Mo and inner Ti layers (labeled $C_{I}$ in Figs. 2 and 5(d)). This binding energy is higher than the corresponding energies in $\mathrm{TiC}$ ( 281.7 to $281.9 \mathrm{eV}), \mathrm{Ti}_{3} \mathrm{AlC}_{2}$ $(281.5 \mathrm{eV}),{ }^{50-52,54}$ or $\mathrm{Mo}_{2} \mathrm{C}(282.7 \mathrm{eV}){ }^{49}$ The other two peaks correspond to $\mathrm{C}-\mathrm{C}$ and $\mathrm{CH}_{\mathrm{x}}$ species that are due to adventitious $\mathrm{C}$ and contamination from the atmosphere.

Crucially, in addition to a $\mathrm{C} 1 \mathrm{~s}$ peak at $282.5 \mathrm{eV}$-with the same full width at half maximum (FWHM) as that in $\mathrm{Mo}_{2} \mathrm{TiAlC}_{2}$ - an extra peak at $281.9 \mathrm{eV}$ is observed in the 413 spectra (Fig. 5(d)). Since this $\mathrm{E}_{\mathrm{B}}$ is comparable to that of $\mathrm{C}$ in $\mathrm{TiC}$ and $\mathrm{Ti}_{3} \mathrm{AlC}_{2}$, we assign it to $\mathrm{C}$ atoms bonded to the inner Ti layers (labeled $\mathrm{C}_{\mathrm{II}}$ in Figs. 2(b) and 5(d)). The fact that the $\mathrm{C}_{\mathrm{I}}$ to $\mathrm{C}_{\mathrm{II}}$ ratio is 2 is fully consistent with their assignments.

\section{Global chemistries}

EDS analysis in the SEM on individual particles showed the ratios of Mo:Ti:Al to be 2.1 \pm 0.3:0.9 \pm 0.2:0.9 \pm 0.1 and 1.9 \pm 0.1:2.0 \pm 0.2:0.9 \pm 0.1 for approximate chemistries of $\mathrm{Mo}_{2.1} \mathrm{Ti}_{0.9} \mathrm{Al}_{0.9}$ and $\mathrm{Mo}_{1.9} \mathrm{Ti}_{2.0} \mathrm{Al}_{0.9}$. To quantify the C- and other elements' content, we combined XPS global elemental analysis (Table S3) ${ }^{46}$ and the species extracted from the peak fitting of XPS high-resolution regions (Tables S1 and S2). ${ }^{46}$ Based on these results, the chemical formulae for $\mathrm{Mo}_{2} \mathrm{TiAlC}_{2}$ and $\mathrm{Mo}_{2} \mathrm{Ti}_{2} \mathrm{AlC}_{3}$ are determined to be $\mathrm{Mo}_{2} \mathrm{TiAlC}_{1.7}$ and $\mathrm{Mo}_{2} \mathrm{Ti}_{1.9} \mathrm{Al}_{0.9} \mathrm{C}_{2.5}$, respectively. These values are not too different from those determined from the EDS results lending credence to the totality of our results and methodologies. At 85\%, the C-occupancy in the 413 phase is not statistically significantly different from the $83.33 \%$ in the 312 phase. Note that for the 413 phase we deliberately started with a lower $\mathrm{C}$ amount, as others have. ${ }^{56}$ The fact that the $\mathrm{C}$-sites are not fully occupied suggests that $\mathrm{C}$-vacancies may be needed to stabilize these structures.

\section{E. Resistivity versus temperature}

Figure 6 shows the resistivity, $\rho$, versus temperature, T, results of the $\mathrm{Mo}_{2} \mathrm{TiAlC}_{2}$ (red, left y-axis) and $\mathrm{Mo}_{2} \mathrm{Ti}_{2} \mathrm{AlC}_{3}$ (blue, right y-axis) samples. At $150 \mu \Omega \mathrm{cm}$, the measured resistivity value of the $\mathrm{Mo}_{2} \mathrm{TiAlC}_{2}$ sample at $10 \mathrm{~K}$ is lower than that of the $\mathrm{Mo}_{2} \mathrm{Ti}_{2} \mathrm{AlC}_{3}(817 \mu \Omega \mathrm{cm})$ sample. The main reason for showing these results is to prove that-like in most MAX phases ${ }^{3}$ - the conductivity is metal-like. Given the level of porosity and impurities in the samples measured, these results have to be used with caution, since they are most probably far from the intrinsic values. Note also that the resistivity curves shown are cropped at $10 \mathrm{~K}$; below this temperature, artifacts originating from the possible presence of a superconducting impurity phase (e.g., molybdenum carbide) were observed (see Fig. S2). ${ }^{46}$

\section{THEORETICAL ANALYSIS}

For the $\mathrm{Mo}_{2} \mathrm{TiAlC}_{2}$ composition, six different ordered structures, defined in Table $\mathrm{S}^{46}$ and schematically depicted 
TABLE III. Summary of unit cell volumes, a and c lattice parameters, the calculated total energy $\mathrm{E}_{0}$, of quaternaries in the $\mathrm{Mo}_{\mathrm{m}} \mathrm{Ti}_{3-\mathrm{m}} \mathrm{AlC}_{2}$ as a function of $\mathrm{m}$. Also listed are the formation energies relative to those of the most competing phases, $\Delta \mathrm{H}_{\mathrm{cp}}$, listed in the last column. The letters in brackets in the first column refer to those shown in Fig. 7(a). SQS refers to quasi random structures.

\begin{tabular}{|c|c|c|c|c|c|c|}
\hline$m$ & $V\left(\AA^{3} / \mathrm{uc}\right)$ & $a(\AA)$ & $c(\AA)$ & $E_{0}(\mathrm{eV} / \mathrm{fu})^{\mathrm{a}}$ & Set of most competing phases & $\Delta H_{c p}(\mathrm{meV} / \mathrm{atom})$ \\
\hline $0\left(\mathrm{Ti}_{3} \mathrm{AlC}_{2}\right)$ & 153.46 & 3.0832 & 18.640 & -49.884 & $\mathrm{Ti}_{5} \mathrm{Al}_{2} \mathrm{C}_{3}, \mathrm{Ti}_{7} \mathrm{Al}_{2} \mathrm{C}_{5}$ & -6 \\
\hline $3\left(\mathrm{Mo}_{3} \mathrm{AlC}_{2}\right)$ & 151.48 & 3.0714 & 18.542 & -54.831 & $\mathrm{C}, \mathrm{Mo}_{3} \mathrm{Al}$ & 141 \\
\hline 0.5 (SQS) & 151.60 & 3.0760 & 18.500 & -51.029 & $\mathrm{TiC}, \mathrm{Mo}_{3} \mathrm{Al}, \mathrm{Mo}_{3} \mathrm{Al}_{8}, \mathrm{Ti}_{4} \mathrm{AlC}_{3}$ & 4 \\
\hline 0.75 (SQS) & 150.58 & 3.0639 & 18.522 & -51.575 & $\mathrm{TiC}, \mathrm{Mo}_{3} \mathrm{Al}, \mathrm{Mo}_{3} \mathrm{Al}_{8}, \mathrm{Ti}_{4} \mathrm{AlC}_{3}$ & 11 \\
\hline $1(\mathrm{~A})$ & 152.64 & 3.0854 & 18.516 & -51.677 & $\mathrm{TiC}, \mathrm{Mo}_{3} \mathrm{Al}, \mathrm{Mo}_{3} \mathrm{Al}_{8}$ & 91 \\
\hline $1(\mathrm{~B})$ & 151.42 & 3.0713 & 18.537 & -51.892 & $\mathrm{TiC}, \mathrm{Mo}_{3} \mathrm{Al}, \mathrm{Mo}_{3} \mathrm{Al}_{8}$ & 55 \\
\hline $1(\mathrm{C})$ & 150.12 & 3.0578 & 18.539 & -52.170 & $\mathrm{TiC}, \mathrm{Mo}_{3} \mathrm{Al}, \mathrm{Mo}_{3} \mathrm{Al}_{8}$ & 9 \\
\hline 1 (D) & 150.52 & 3.0622 & 18.534 & -52.079 & $\mathrm{TiC}, \mathrm{Mo}_{3} \mathrm{Al}, \mathrm{Mo}_{3} \mathrm{Al}_{8}$ & 24 \\
\hline $1(\mathrm{E})$ & 151.66 & 3.0546 & 18.768 & -51.577 & $\mathrm{TiC}, \mathrm{Mo}_{3} \mathrm{Al}, \mathrm{Mo}_{3} \mathrm{Al}_{8}$ & 108 \\
\hline $1(\mathrm{~F})$ & 149.78 & 3.0425 & 18.683 & -52.141 & $\mathrm{TiC}, \mathrm{Mo}_{3} \mathrm{Al}, \mathrm{Mo}_{3} \mathrm{Al}_{8}$ & 14 \\
\hline 1 (SQS) & 150.40 & 3.0587 & 18.557 & -52.003 & $\mathrm{TiC}, \mathrm{Mo}_{3} \mathrm{Al}, \mathrm{Mo}_{3} \mathrm{Al}_{8}$ & 37 \\
\hline 1.25 (SQS) & 150.10 & 3.0539 & 18.580 & -52.447 & $\mathrm{Ti}_{2} \mathrm{Mo}_{2} \mathrm{AlC}_{3}, \mathrm{TiC}, \mathrm{Mo}_{3} \mathrm{Al}, \mathrm{Mo}_{3} \mathrm{Al}_{8}$ & 55 \\
\hline $1.5(\mathrm{SQS})$ & 149.28 & 3.0399 & 18.661 & -52.954 & $\mathrm{Ti}_{2} \mathrm{Mo}_{2} \mathrm{AlC}_{3}, \mathrm{TiC}, \mathrm{Mo}_{3} \mathrm{Al}, \mathrm{Mo}_{3} \mathrm{Al}_{8}$ & 63 \\
\hline 1.5 (A with partial Ti on $4 \mathrm{f}$ ) & 147.60 & 3.0185 & 18.706 & -53.291 & $\mathrm{Ti}_{2} \mathrm{Mo}_{2} \mathrm{AlC}_{3}, \mathrm{TiC}, \mathrm{Mo}_{3} \mathrm{Al}, \mathrm{Mo}_{3} \mathrm{Al}_{8}$ & 7 \\
\hline 1.75 (SQS) & 149.18 & 3.0342 & 18.707 & -53.339 & $\mathrm{Ti}_{2} \mathrm{Mo}_{2} \mathrm{AlC}_{3}, \mathrm{Mo}_{3} \mathrm{Al}, \mathrm{Mo}_{3} \mathrm{Al}_{8}$ & 81 \\
\hline 1.75 (A with partial $\mathrm{Ti}$ on $4 \mathrm{f}$ ) & 147.20 & 3.0093 & 18.771 & -53.808 & $\mathrm{Ti}_{2} \mathrm{Mo}_{2} \mathrm{AlC}_{3}, \mathrm{Mo}_{3} \mathrm{Al}, \mathrm{Mo}_{3} \mathrm{Al}_{8}$ & 3 \\
\hline $2(\mathrm{~A})$ & 147.00 & 3.0082 & 18.757 & -54.305 & $\mathrm{Ti}_{2} \mathrm{Mo}_{2} \mathrm{AlC}_{3}, \mathrm{Mo}_{3} \mathrm{Al}, \mathrm{Mo}_{3} \mathrm{Al}_{8}$ & -18 \\
\hline $2(\mathrm{~B})$ & 148.78 & 3.0217 & 18.815 & -53.762 & $\mathrm{Ti}_{2} \mathrm{Mo}_{2} \mathrm{AlC}_{3}, \mathrm{Mo}_{3} \mathrm{Al}, \mathrm{Mo}_{3} \mathrm{Al}_{8}$ & 72 \\
\hline $2(\mathrm{C})$ & 150.48 & 3.0352 & 18.863 & -53.239 & $\mathrm{Ti}_{2} \mathrm{Mo}_{2} \mathrm{AlC}_{3}, \mathrm{Mo}_{3} \mathrm{Al}, \mathrm{Mo}_{3} \mathrm{Al}_{8}$ & 159 \\
\hline 2 (D) & 150.64 & 3.0377 & 18.850 & -53.192 & $\mathrm{Ti}_{2} \mathrm{Mo}_{2} \mathrm{AlC}_{3}, \mathrm{Mo}_{3} \mathrm{Al}, \mathrm{Mo}_{3} \mathrm{Al}_{8}$ & 167 \\
\hline $2(\mathrm{E})$ & 150.68 & 3.0632 & 18.542 & -53.502 & $\mathrm{Ti}_{2} \mathrm{Mo}_{2} \mathrm{AlC}_{3}, \mathrm{Mo}_{3} \mathrm{Al}, \mathrm{Mo}_{3} \mathrm{Al}_{8}$ & 116 \\
\hline $2(\mathrm{~F})$ & 151.60 & 3.0740 & 18.524 & -53.271 & $\mathrm{Ti}_{2} \mathrm{Mo}_{2} \mathrm{AlC}_{3}, \mathrm{Mo}_{3} \mathrm{Al}, \mathrm{Mo}_{3} \mathrm{Al}_{8}$ & 154 \\
\hline $2(\mathrm{SQS})$ & 150.02 & 3.0442 & 18.683 & -53.545 & $\mathrm{Ti}_{2} \mathrm{Mo}_{2} \mathrm{AlC}_{3}, \mathrm{Mo}_{3} \mathrm{Al}, \mathrm{Mo}_{3} \mathrm{Al}_{8}$ & 108 \\
\hline 2.25 (SQS) & 150.22 & 3.0477 & 18.681 & -53.887 & $\mathrm{Ti}_{2} \mathrm{Mo}_{2} \mathrm{AlC}_{3}, \mathrm{Mo}_{3} \mathrm{Al}, \mathrm{Mo}_{3} \mathrm{Al}_{8}$ & 113 \\
\hline
\end{tabular}

${ }^{\mathrm{a}}$ fu refers to formula unit, which is half a unit cell.

in Fig. 7(a), and one disordered SQS (e.g., structure I in Fig. 10(a)) were considered. For the $\mathrm{Mo}_{2} \mathrm{Ti}_{2} \mathrm{AlC}_{3}$ composition, 20 different ordered structures, defined in Table $\mathrm{S} 5,{ }^{46}$ and one disordered SQS (e.g., structure I in Fig. 10(a)) were considered. Six of the 20 structures are shown schematically in Fig. 7(b). In both Figs. 7(a) and 7(b), the unit cells are sorted with increasing energy from left to right. The unit cells of type A structures are shown in Fig. 2.

A summary of the unit cell volumes, $\mathrm{V}_{\mathrm{UC}}, a$ and $c$ lattice parameters, the calculated total energy, $\mathrm{E}_{0}$, of the quaternaries $\mathrm{Mo}_{\mathrm{m}} \mathrm{Ti}_{3-\mathrm{m}} \mathrm{AlC}_{2}$ and $\mathrm{Mo}_{\mathrm{m}} \mathrm{Ti}_{4-\mathrm{m}} \mathrm{AlC}_{2}$, as a function of $\mathrm{m}$ are listed in Tables III and IV, respectively. Also listed are the formation energies relative to the most competing phases, $\Delta \mathrm{H}_{\mathrm{cp}}$, listed in the last column. Based on the results listed in Table III, it is clear that the $a$ lattice parameters of unit cell type $\mathrm{A}$ for $\mathrm{Mo}_{2} \mathrm{TiAlC}_{2}$ are considerably reduced $(-2.1 . \%$ to $-2.4 \%)$ in comparison to the end members, $\mathrm{Ti}_{3} \mathrm{AlC}_{2}$ and $\mathrm{Mo}_{3} \mathrm{AlC}_{2}$. In contradistinction, the $c$-lattice parameter increases $(+0.6 \%$ and $+1.2 \%)$. The $\mathrm{V}_{\mathrm{UC}}$ values shrink accordingly.

The same is true of $\mathrm{Mo}_{2} \mathrm{Ti}_{2} \mathrm{AlC}_{3}$ (Table IV) in comparison to its end members, $\mathrm{Ti}_{4} \mathrm{AlC}_{3}$ and $\mathrm{Mo}_{4} \mathrm{AlC}_{3}$. Here again the $a$ lattice parameter and $\mathrm{V}_{\mathrm{UC}}$ values decrease, as the $c$ lattice parameters increase.

The formation enthalpies, $\Delta H_{c p}$, calculated for $\mathrm{Mo}_{\mathrm{m}} \mathrm{Ti}_{3-\mathrm{m}} \mathrm{AlC}_{2}$ relative to their most likely competing phases (listed in the last column of Table III) are plotted in Fig. 8(a) as a function of $m$. Also plotted, as crosses in
Fig. 8, are the $\Delta H_{c p}$ values for solid solutions of Mo and Ti. In such figures, any composition with a negative $\Delta H_{c p}$ can exist; those with positive $\Delta H_{c p}$ values should not. Based on these results, only $\mathrm{Ti}_{3} \mathrm{AlC}_{2}$ and a type $\mathrm{A}, \mathrm{Mo}_{\mathrm{m}} \mathrm{Ti}_{3-\mathrm{m}} \mathrm{AlC}_{2}$ structure with $\mathrm{m}=2$, viz., $\mathrm{Mo}_{2} \mathrm{TiAlC}_{2}$ can exist as observed in this and previous work. ${ }^{27}$ Note that the $-6 \mathrm{meV} /$ atom value for $\mathrm{Ti}_{3} \mathrm{AlC}_{2}$ is different from previous work, ${ }^{39}$ since here we included more competing higher order MAX phases, such as $\mathrm{Ti}_{5} \mathrm{Al}_{2} \mathrm{C}_{3}$ and $\mathrm{Ti}_{7} \mathrm{Al}_{2} \mathrm{C}_{5}$ that are also stable. The value of $\Delta H_{c p}$ for the ordered $\mathrm{Mo}_{2} \mathrm{TiAlC}_{2}$ type A structure is $-18 \mathrm{meV} / \mathrm{atom}$, which means an energetically preferred structure, consistent with experimental observations. Interestingly, the type $\mathrm{A} \mathrm{Mo}_{2} \mathrm{Ti}_{2} \mathrm{AlC}_{3}$ structure is one of its most competing phases. Also noteworthy is the much higher energy of all other ordered structures with $\mathrm{m}=2$, wherein the Mo atoms are surrounded by $\mathrm{C}$ in FCC arrangement, i.e., not adjacent to the Al-layers (Fig. 8(a)). Here, again is a good example of the steep cost in energy for any structure in which the Mo atoms are surrounded by $\mathrm{C}$ atoms that are in an FCC arrangement.

For $\mathrm{m}=1$, or the $\mathrm{MoTi}_{2} \mathrm{AlC}_{2}$ composition, the type A structure is even less stable than the solid solution ( $+37 \mathrm{meV} /$ atom). Interestingly, for $\mathrm{m}=1$, the C-type unit cell has the lowest energy.

The functional dependencies of $\Delta H_{c p}$ on $\mathrm{m}$-calculated for $\mathrm{Mo}_{\mathrm{m}} \mathrm{Ti}_{4-\mathrm{m}} \mathrm{AlC}_{3}$ relative to their most likely competing phases (listed in the last column of Table IV) - are plotted in Fig. 8 (b). Here again, at $\mathrm{m}=2$, with $\Delta H_{c p}=-17 \mathrm{meV} /$ atom, 
TABLE IV. Summary of unit cell volumes, a and c lattice parameters, the calculated total energy, $\mathrm{E}_{0}$, of quaternaries in the $\mathrm{Mo}_{\mathrm{m}} \mathrm{Ti}_{4-\mathrm{m}} \mathrm{AlC}_{3}$ as a function of $\mathrm{m}$. Also listed are the formation energies relative to those of the most competing phases, $\Delta \mathrm{H}_{\mathrm{cp}}$, listed in the last column. The letters in brackets in the first column refer to those shown in Fig. 7(b) and Fig. 8(b). SQS refers to quasi random structures.

\begin{tabular}{|c|c|c|c|c|c|c|}
\hline$m$ & $V\left(\AA^{3} / \mathrm{uc}\right)$ & $a(\AA)$ & $c(\AA)$ & $E_{0}(\mathrm{eV} / \mathrm{fu})^{\mathrm{a}}$ & Set of most competing phases & $\Delta H_{c p}(\mathrm{meV} /$ atom $)$ \\
\hline $0\left(\mathrm{Ti}_{4} \mathrm{AlC}_{3}\right)$ & 194.48 & 3.0859 & 23.582 & -68.413 & $\mathrm{Ti}_{3} \mathrm{AlC}_{2}, \mathrm{TiC}$ & 0 \\
\hline $4\left(\mathrm{Mo}_{4} \mathrm{AlC}_{3}\right)$ & 196.50 & 3.1167 & 23.358 & -74.552 & $\mathrm{C}, \mathrm{MoC}, \mathrm{Mo}_{3} \mathrm{Al}$ & 171 \\
\hline 1 (A with partial Mo on $4 \mathrm{f}$ ) & 190.12 & 3.0543 & 23.534 & -70.766 & $\mathrm{TiC}, \mathrm{Mo}_{3} \mathrm{Al}, \mathrm{Mo}_{3} \mathrm{Al}_{8}$ & -2 \\
\hline 1 (SQS) & 191.48 & 3.0577 & 23.652 & -71.331 & $\mathrm{TiC}, \mathrm{Mo}_{3} \mathrm{Al}, \mathrm{Mo}_{3} \mathrm{Al}_{8}$ & 21 \\
\hline 1.5 (A with partial Mo on 4f) & 188.51 & 3.0323 & 23.673 & -71.902 & $\mathrm{TiC}, \mathrm{Mo}_{2} \mathrm{TiAlC}_{2}, \mathrm{Mo}_{3} \mathrm{Al}, \mathrm{Mo}_{3} \mathrm{Al}_{8}$ & -13 \\
\hline $1.5(\mathrm{SQS})$ & 191.31 & 3.0641 & 23.530 & -70.583 & $\mathrm{TiC}, \mathrm{Mo}_{2} \mathrm{TiAlC}_{2}, \mathrm{Mo}_{3} \mathrm{Al}, \mathrm{Mo}_{3} \mathrm{Al}_{8}$ & 58 \\
\hline 2 (type A) & 187.87 & 3.0280 & 23.659 & -72.969 & $\mathrm{TiC}, \mathrm{Mo}_{2} \mathrm{TiAlC}_{2}$ & -17 \\
\hline 2 (type B) & 194.28 & 3.0712 & 23.784 & -71.453 & $\mathrm{TiC}, \mathrm{Mo}_{2} \mathrm{TiAlC}_{2}$ & 173 \\
\hline 2 (type C) & 189.36 & 3.0381 & 23.690 & -72.699 & $\mathrm{TiC}, \mathrm{Mo}_{2} \mathrm{TiAlC}_{2}$ & 17 \\
\hline 2 (type D) & 191.09 & 3.0501 & 23.719 & -72.228 & $\mathrm{TiC}, \mathrm{Mo}_{2} \mathrm{TiAlC}_{2}$ & 76 \\
\hline 2 (type E) & 191.80 & 3.0559 & 23.716 & -71.991 & $\mathrm{TiC}, \mathrm{Mo}_{2} \mathrm{TiAlC}_{2}$ & 105 \\
\hline 2 (type F) & 191.64 & 3.0538 & 23.729 & -72.063 & $\mathrm{TiC}, \mathrm{Mo}_{2} \mathrm{TiAlC}_{2}$ & 96 \\
\hline 2 (type G) & 192.50 & 3.0621 & 23.706 & -71.701 & $\mathrm{TiC}, \mathrm{Mo}_{2} \mathrm{TiAlC}_{2}$ & 142 \\
\hline 2 (type $\mathrm{H}$ ) & 190.24 & 3.0438 & 23.710 & -72.313 & $\mathrm{TiC}, \mathrm{Mo}_{2} \mathrm{TiAlC}_{2}$ & 65 \\
\hline 2 (type I) & 193.00 & 3.0668 & 23.694 & -71.586 & $\mathrm{TiC}, \mathrm{Mo}_{2} \mathrm{TiAlC}_{2}$ & 156 \\
\hline 2 (type $J$ ) & 193.08 & 3.0823 & 23.466 & -71.838 & $\mathrm{TiC}, \mathrm{Mo}_{2} \mathrm{TiAlC}_{2}$ & 125 \\
\hline 2 (type K) & 190.98 & 3.0548 & 23.632 & -72.252 & $\mathrm{TiC}, \mathrm{Mo}_{2} \mathrm{TiAlC}_{2}$ & 73 \\
\hline 2 (type L) & 191.49 & 3.0582 & 23.641 & -72.243 & $\mathrm{TiC}, \mathrm{Mo}_{2} \mathrm{TiAlC}_{2}$ & 74 \\
\hline 2 (type M) & 193.45 & 3.0797 & 23.552 & -71.762 & $\mathrm{TiC}, \mathrm{Mo}_{2} \mathrm{TiAlC}_{2}$ & 134 \\
\hline 2 (type $\mathrm{N}$ ) & 190.83 & 3.0475 & 23.726 & -72.446 & $\mathrm{TiC}, \mathrm{Mo}_{2} \mathrm{TiAlC}_{2}$ & 49 \\
\hline 2 (type O) & 190.83 & 3.0484 & 23.712 & -72.398 & $\mathrm{TiC}, \mathrm{Mo}_{2} \mathrm{TiAlC}_{2}$ & 55 \\
\hline 2 (type P) & 194.40 & 3.0956 & 23.425 & -71.536 & $\mathrm{TiC}, \mathrm{Mo}_{2} \mathrm{TiAlC}_{2}$ & 162 \\
\hline 2 (type Q) & 193.52 & 3.0681 & 23.739 & -71.540 & $\mathrm{TiC}, \mathrm{Mo}_{2} \mathrm{TiAlC}_{2}$ & 162 \\
\hline 2 (type R) & 192.56 & 3.0601 & 23.744 & -71.942 & $\mathrm{TiC}, \mathrm{Mo}_{2} \mathrm{TiAlC}_{2}$ & 112 \\
\hline 2 (type $S$ ) & 193.52 & 3.0681 & 23.739 & -71.540 & $\mathrm{TiC}, \mathrm{Mo}_{2} \mathrm{TiAlC}_{2}$ & 162 \\
\hline $2(\mathrm{SQS})$ & 191.36 & 3.0560 & 23.647 & -72.267 & $\mathrm{TiC}, \mathrm{Mo}_{2} \mathrm{TiAlC}_{2}$ & 71 \\
\hline 2.5 (A with partial Ti on 4e) & 189.76 & 3.0410 & 23.691 & -73.602 & $\mathrm{Mo}_{2} \mathrm{TiAlC}_{2}, \mathrm{MoC}, \mathrm{TiC}$ & 11 \\
\hline $2.5(\mathrm{SQS})$ & 191.88 & 3.0644 & 23.598 & -73.090 & $\mathrm{Mo}_{2} \mathrm{TiAlC}_{2}, \mathrm{MoC}, \mathrm{TiC}$ & 75 \\
\hline 3 (A with partial Ti on 4e) & 191.89 & 3.0659 & 23.571 & -73.991 & $\mathrm{Mo}_{2} \mathrm{TiAlC}_{2}, \mathrm{MoC}$ & 69 \\
\hline 3 (SQS) & 193.66 & 3.0838 & 23.500 & -73.450 & $\mathrm{Mo}_{2} \mathrm{TiAlC}_{2}, \mathrm{MoC}$ & 137 \\
\hline
\end{tabular}

${ }^{\mathrm{a}}$ fu refers to formula unit, which is half a unit cell.

only type A structure is stable. At this composition, $\mathrm{Mo}_{2} \mathrm{TiAlC}_{2}$ (type A) is one of its most competing phases. At $+71 \mathrm{meV} / \mathrm{atom}$, the solid solution of Ti and Mo on the $M$ sites is not stable. Furthermore, at this composition, the least stable structure is type $\mathrm{B}$, where only Ti layers are adjacent to the Al-layers and all Mo layers are in between the $\mathrm{Ti}$ layers. Note that for the $\mathrm{Mo}_{2} \mathrm{Ti}_{2} \mathrm{AlC}_{3}$ composition, type $\mathrm{B}$ is the inverse of type A (compare type A and type B structures in Fig. 7(b)).

It follows that for both the $\mathrm{Mo}_{m} \mathrm{Ti}_{3-m} \mathrm{AlC}_{2}$ and $\mathrm{Mo}_{m} \mathrm{Ti}_{4-m} \mathrm{AlC}_{3}$ compositions, there is a strong driving force for the formation of structures where the C-Mo-C bonds, in FCC arrangement, are minimized and the Mo- $\mathrm{Al}$ bonds are maximized. In both systems, this occurs at $m=2$ with type A layering. Another way to illustrate this important conclusion - that is well confirmed experimentally (see Table II) is to plot $\Delta H_{c p}$ as the fraction of $\mathrm{Mo} /(\mathrm{Mo}+\mathrm{Ti})$ atoms surrounded by $\mathrm{C}$ in FCC arrangement (Fig. 9). Based on these results, it is clear that the only stable structure is type A, where $\mathrm{C}-\mathrm{Mo}-\mathrm{C}$ (in FCC) bonds do not exist, i.e., for Mo/ $(\mathrm{Mo}+\mathrm{Ti})=0$ in Fig. 9. This does not necessarily imply that Mo and $\mathrm{C}$ do not form strong bonds-after all $\mathrm{MoC}$ is one of the most stable binary carbides known-but rather that the $\mathrm{HCP}$ arrangement of $\mathrm{C}$ is much preferred. Interestingly,
Hugosson et al. also showed that while vacancies destabilized hexagonal MoC, they rendered the rock salt structure more stable. ${ }^{47}$ Some may argue that the stability of the ordered structures could be related to the presence of Mo-Al bonds. However, the fact that the $\mathrm{Mo}_{2} \mathrm{AlC}$ phase does not exist argues against this idea.

The results, summarized in Table II, confirm there is some intermixing between the Ti and Mo layers, a not too surprising result since our samples were fabricated at $1873 \mathrm{~K}$. Thus the pertinent question to ask here is by how much can the compositions deviate from $m=2$ and still remain stable? To answer this question, we started with a type A structure and created solid solutions on one of the $M$-sites, a so-called partial SQS. The results of such calculations-shown in Figs. 8(a) and 8(b) by dashed lines-show that for both chemistries, such mixing results in less stable structures. For the $\mathrm{Mo}_{m} \mathrm{Ti}_{3-m} \mathrm{AlC}_{2}$ compositions, $\Delta H_{c p}<0$ between $1.8<\mathrm{m}<2.15$ (see Fig. 8(a)). In the $\mathrm{Mo}_{m} \mathrm{Ti}_{4-m} \mathrm{AlC}_{3}$ case, $\Delta H_{c p}<0$, over a wider $\mathrm{m}$ range, viz., between $1<\mathrm{m}<2.3$ (see Fig. 8(b)). Given the aversion of the Mo atoms to be surrounded by $\mathrm{C}$ atoms in an FCC arrangement, it is not surprising that the minimum in Fig. 8(b) is non-symmetric and skewed to the Ti-side. Why this is not the case for the 312 phase (Fig. 8(a)) is less clear at this time. Note that in 

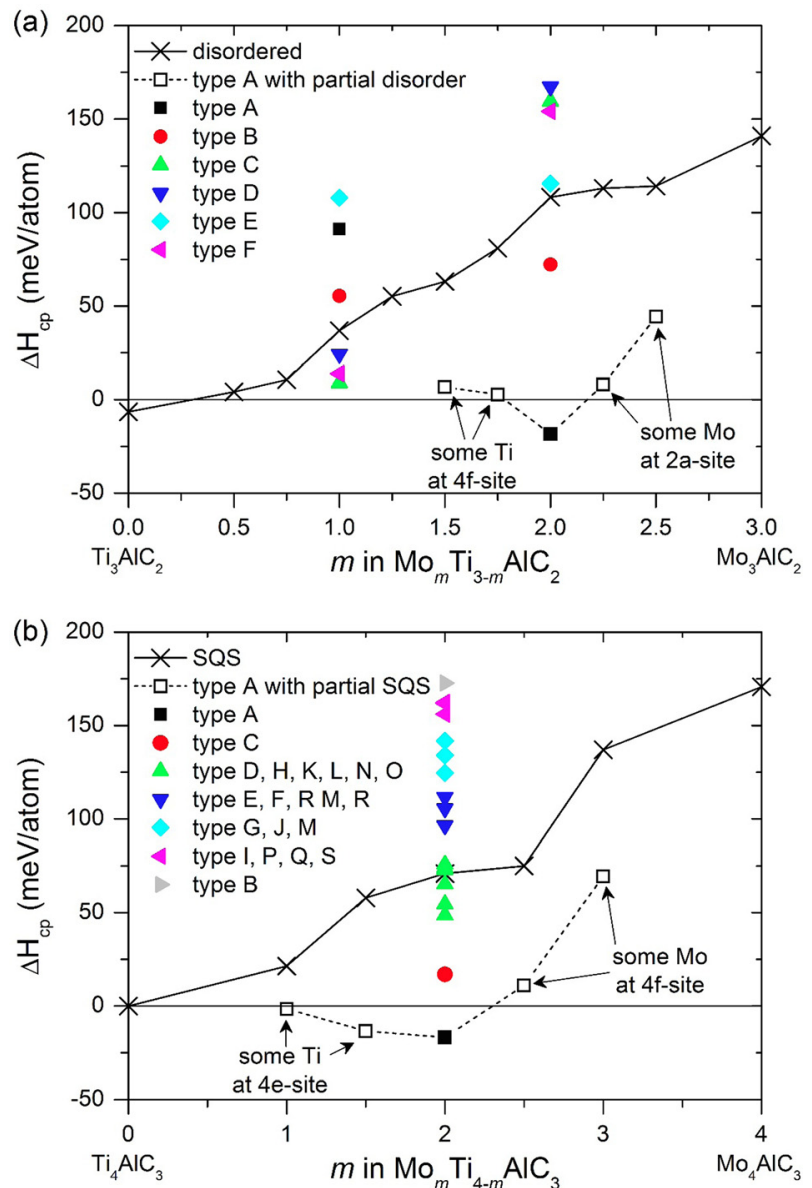

FIG. 8. Formation enthalpy $\Delta H_{c p}$ of, (a) $\mathrm{Mo}_{m} \mathrm{Ti}_{3-m} \mathrm{AlC}_{2}$ and (b) $\mathrm{Mo}_{m} \mathrm{Ti}_{4-m} \mathrm{AlC}_{3}$ phases as a function of $m$ for ordered (filled symbols), partially disordered (open squares), and disordered distributions (crosses) of Mo and Ti. Negative $\Delta H_{c p}$ values indicate stability compared to the set of most competing phases.

Fig. 8, when some of the Mo atoms-on the $4 f$ - or $4 e$-sites in 312 or 413 structures, respectively_are replaced by Ti, $\mathrm{m}$ decreases. Conversely, when some of the Ti atoms on the $2 a$ - or $4 f$-sites are replaced by Mo, $\mathrm{m}$ increases.

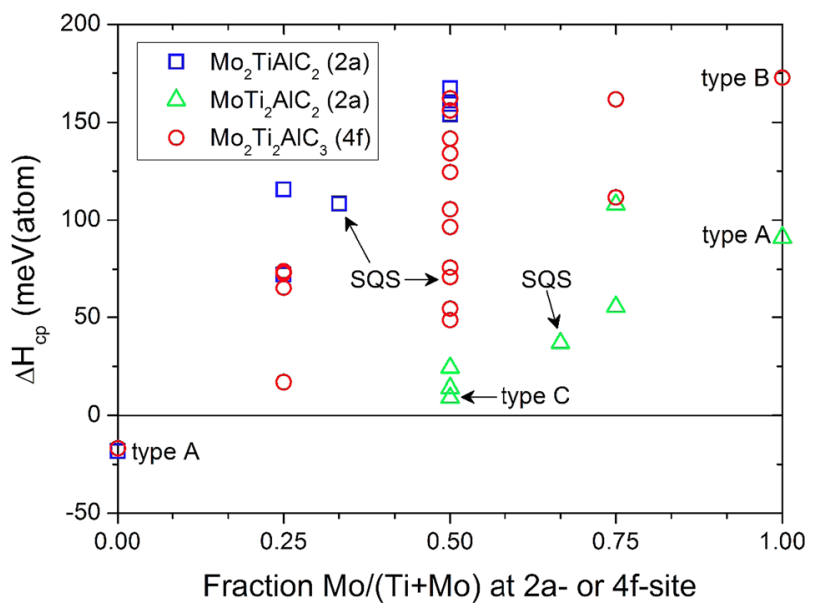

FIG. 9. Formation enthalpy, $\Delta H_{c p}$, of $\mathrm{Mo}_{2} \mathrm{TiAlC}_{2}, \mathrm{MoTi}_{2} \mathrm{AlC}$, and $\mathrm{Mo}_{2} \mathrm{Ti}_{2} \mathrm{AlC}_{3}$ as a function of the fraction of $\mathrm{Mo}$ atoms, given by $\mathrm{Mo} /$ (Mo+Ti) facing the $\mathrm{Al}$ layers on the $4 \mathrm{f}\left(\mathrm{Mo}_{2} \mathrm{TiAlC}_{2}\right.$ and $\left.\mathrm{MoTi}_{2} \mathrm{AlC}_{2}\right)$ or $4 \mathrm{e}$ $\left(\mathrm{Mo}_{2} \mathrm{Ti}_{2} \mathrm{AlC}_{3}\right) M$-sites. In this figure only type $\mathrm{A}$ is stable and has the lowest energy compared to its most competing phases.
TABLE V. Calculated lattice parameters and atomic occupancies of Mo and $\mathrm{Ti}$ atoms on the $M$-sites for ordered, semi-ordered, and disordered distributions of $\mathrm{Mo}$ and $\mathrm{Ti}$ in the $\mathrm{Mo}_{2} \mathrm{TiAlC}_{2}$ and $\mathrm{Mo}_{2} \mathrm{Ti}_{2} \mathrm{AlC}_{3}$ phases.

\begin{tabular}{|c|c|c|c|c|c|c|c|c|c|c|}
\hline \multicolumn{11}{|c|}{$\mathrm{Mo}_{2} \mathrm{TiAlC}_{2}$} \\
\hline \multirow{2}{*}{$\begin{array}{l}\text { Degree of } \\
\text { ordering }\end{array}$} & \multicolumn{2}{|c|}{ Lattice parameters } & \multicolumn{2}{|c|}{$\begin{array}{c}2 \mathrm{a} \\
(\%)\end{array}$} & \multirow{2}{*}{\multicolumn{2}{|c|}{$\begin{array}{c}\begin{array}{c}4 \mathrm{f} \\
(\%)\end{array} \\
\mathrm{Ti} \mathrm{Mo}\end{array}$}} & \multicolumn{2}{|c|}{$\begin{array}{c}2 \mathrm{a} \\
\text { (\#atoms) }\end{array}$} & \multicolumn{2}{|c|}{$\begin{array}{c}4 \mathrm{f} \\
\text { (\#atoms) }\end{array}$} \\
\hline & $\mathrm{a}(\AA)$ & c $(\AA)$ & $\mathrm{Ti}$ & Mo & & & $\mathrm{Ti}$ & Mo & $\mathrm{Ti}$ & Mo \\
\hline 1.0000 (type A) & 3.0082 & 18.757 & 100 & 0 & $\begin{array}{ll}0 & 1\end{array}$ & 100 & 2 & 0 & 0 & 4 \\
\hline 0.8125 & 3.0135 & 18.745 & 88 & 13 & 6 & 94 & 28 & 4 & 4 & 60 \\
\hline 0.6250 & 3.0196 & 18.728 & 75 & 25 & 138 & 88 & 24 & 8 & 8 & 56 \\
\hline 0.4375 & 3.0254 & 18.711 & 63 & 38 & 198 & 81 & 20 & 12 & 12 & 52 \\
\hline $0.0000(\mathrm{SQS})$ & 3.0442 & 18.683 & 34 & 66 & 33 & 67 & 11 & 21 & 21 & 43 \\
\hline \multicolumn{11}{|c|}{$\mathrm{Mo}_{2} \mathrm{Ti}_{2} \mathrm{AlC}_{3}$} \\
\hline \multirow{2}{*}{$\begin{array}{l}\text { Degree of } \\
\text { ordering }\end{array}$} & \multicolumn{2}{|c|}{ Lattice parameters } & \multicolumn{2}{|c|}{$\begin{array}{l}4 \mathrm{f} \\
(\%)\end{array}$} & \multicolumn{2}{|c|}{$\begin{array}{l}4 \mathrm{e} \\
(\%)\end{array}$} & \multicolumn{2}{|c|}{$\begin{array}{c}4 \mathrm{f} \\
\text { (\#atoms) }\end{array}$} & \multicolumn{2}{|c|}{$\begin{array}{c}4 \mathrm{e} \\
\text { (\#atoms) }\end{array}$} \\
\hline & $\mathrm{a}(\AA)$ & c $(\AA)$ & $\mathrm{Ti}$ & Mo & Ti $N$ & Mo & $\mathrm{Ti}$ & Mo & $\mathrm{Ti}$ & Mo \\
\hline 1.0000 (type A) & 3.0280 & 23.659 & 100 & 0 & $\begin{array}{ll}0 & 1\end{array}$ & 100 & 4 & 0 & 0 & 4 \\
\hline 0.8125 & 3.0328 & 23.655 & 91 & 9 & 9 & 91 & 58 & 6 & 6 & 58 \\
\hline 0.6250 & 3.0376 & 23.648 & 81 & 19 & 198 & 81 & 52 & 12 & 12 & 52 \\
\hline 0.4375 & 3.0421 & 23.657 & 72 & 28 & 287 & 72 & 46 & 18 & 18 & 46 \\
\hline 0.0000 (SQS) & 3.0560 & 23.647 & 50 & 50 & 50 & 50 & 32 & 32 & 32 & 32 \\
\hline
\end{tabular}

(a)
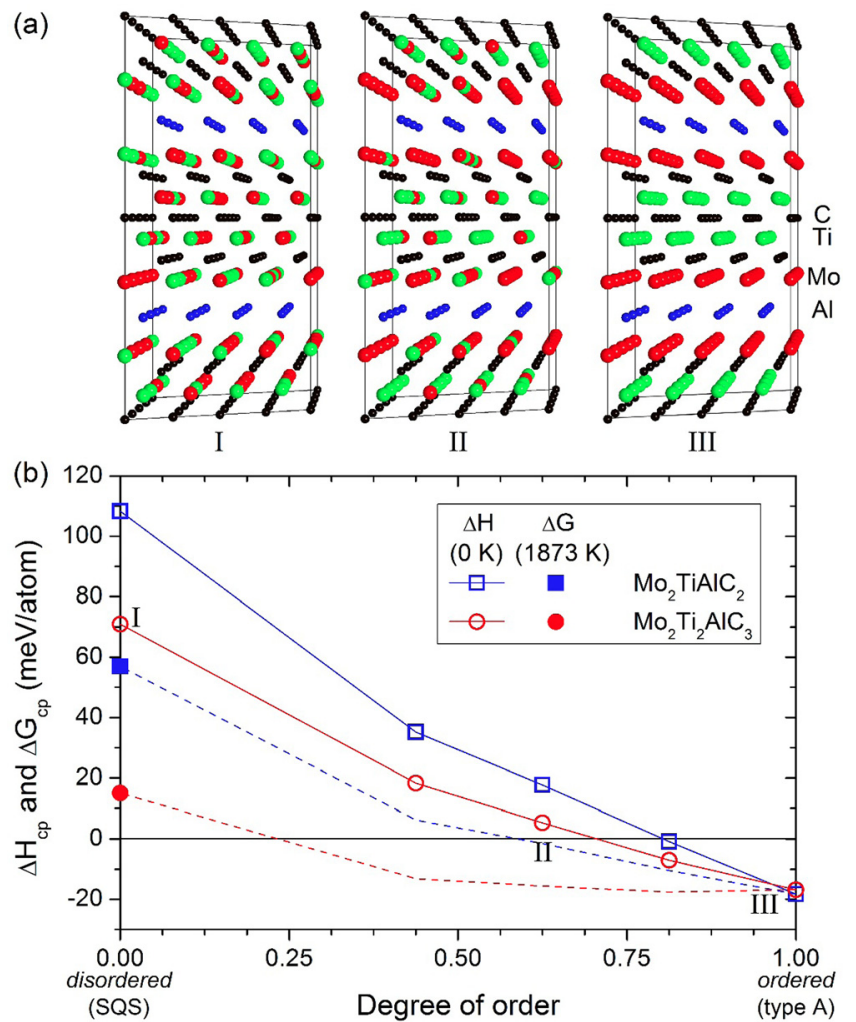

FIG. 10. (a) Schematic of 413 unit cells for (I) a disordered distribution of Mo and Ti using the SQS method, (II) semi-ordered and, (III) complete order of type A. Here, the Mo atoms are colored red, Ti green, $\mathrm{C}$ black, and Al blue. (b) Formation enthalpy of $\mathrm{Mo}_{2} \mathrm{TiAlC}_{2}$ and $\mathrm{Mo}_{2} \mathrm{Ti}_{2} \mathrm{AlC}_{3}$ as a function of the degree of order on the $M$-site. This ranges from 0 for a disordered distribution of Mo and Ti (SQS) to 1 for complete order of type A. For the disordered distribution of Mo and $\mathrm{Ti}$ (SQS), the Gibbs free energy at $1873 \mathrm{~K}$, given by the dashed lines, is estimated (only taking into account configuration entropy). The Gibbs free energy for the semi-ordered/partially ordered structures is estimated using a linear combination of the configurational entropy for the disordered and fully ordered structures. 
As noted above, Table II reveals that there is some intermixing between the Mo and $\mathrm{Ti}$ layers in $\mathrm{Mo}_{2} \mathrm{TiAlC}_{2}$ and $\mathrm{Mo}_{2} \mathrm{Ti}_{2} \mathrm{AlC}_{3}$. This was modeled by keeping the $\mathrm{Mo}_{2} \mathrm{TiAlC}_{2}$ and $\mathrm{Mo}_{2} \mathrm{Ti}_{2} \mathrm{AlC}_{3}$ compositions fixed, while gradually changing the degrees of order/intermixing from complete order of type A (1) to a solid solution (0) (Fig. 9). Detailed information of the occupation of the $\mathrm{Ti}$ and Mo atoms on the various sites as a function of a disorder parameter is given in Table V. Figure 10(a) sketches a fully disordered structure (I), a semi-ordered structure (II) with an order parameter of 0.625 , and the fully ordered Type $\mathrm{A} \mathrm{Mo}_{2} \mathrm{Ti}_{2} \mathrm{AlC}_{3}$ structure (III).

When $\Delta H_{c p}$ is plotted as a function of the degree of order (Fig. 10(b)), it is clear that both compounds can tolerate some disorder, with the 413 compound tolerating more disorder than its 312 counterpart. Based on the extent of intermixing between the Mo and Ti atoms in the phases listed in Table II, one can assume the order parameters for both phases are less than one. It is thus gratifying that the calculated lattice parameters for the fully ordered 312 phase-with $a=3.0135 \AA$ and $\mathrm{c}=18.745 \AA$-are slightly larger than the experimental ones, viz., 2.99718(3) and 18.6614(2) $\AA$, respectively. For the fully ordered 413 phase, the calculated lattice parameters $a=3.0376 \AA$ and $\mathrm{c}=23.648 \AA$ are again slightly larger than experiment, viz., 3.02064(8) $\AA$ and 23.5431(7) $\AA$, respectively. Note that the use of GGA is known to generate slightly overestimated structural parameters.

Up to this point, all calculations were carried out at $0 \mathrm{~K}$. The corresponding free energies are approximated as $\Delta G_{\mathrm{cp}}$
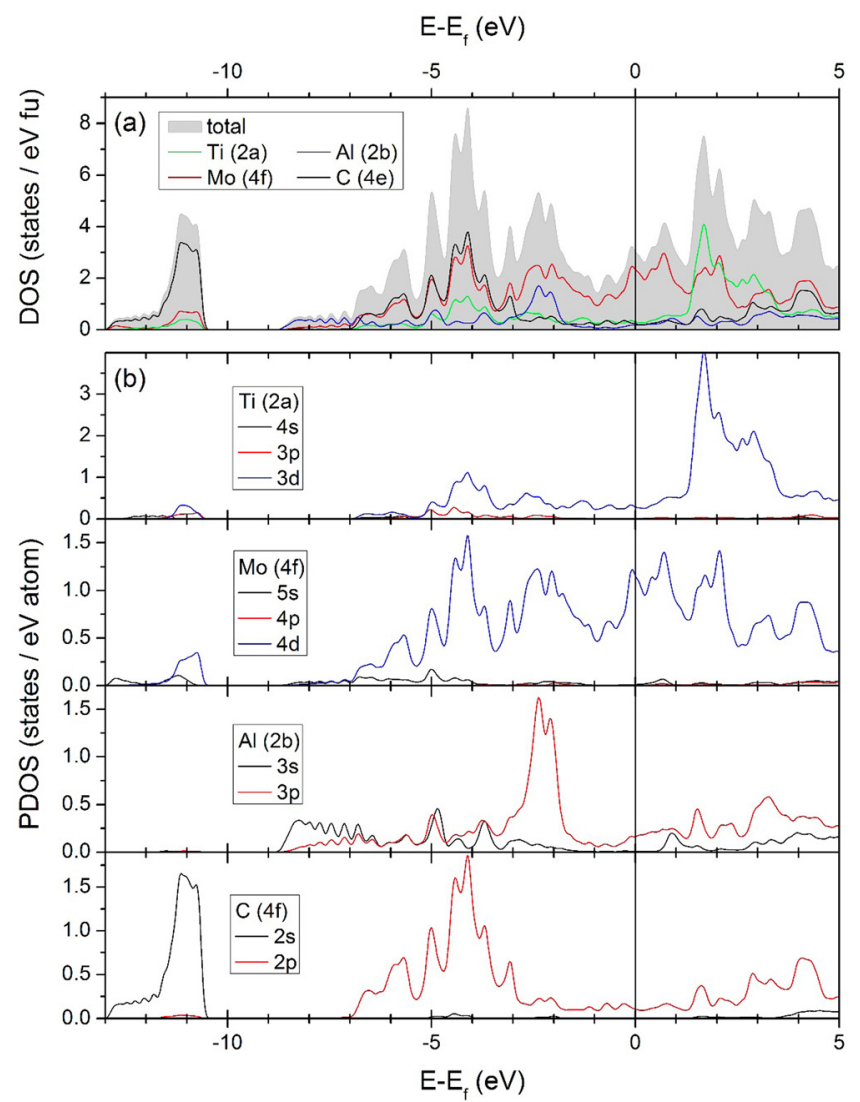

FIG. 11. Density of states (DOS) for type $\mathrm{A} \mathrm{Mo}_{2} \mathrm{TiAlC}_{2}$. (a) Total and atomic DOS and (b) partial DOS for each unique symmetry site. Vertical solid line indicates the location of the Fermi level $E_{f}$.
$=\Delta H_{c p}-T \Delta S$, where $\Delta S=-2 k_{B}[z \ln (z)+(1-z) \ln (1-z)]$ is the configurational entropy change of an ideal solution of Ti and Mo atoms on the $M$-sites, where $k_{B}$ is the Boltzmann constant and $z$ corresponds to the amount of Mo $M$-site $(0<z<1)$. For illustrative purpose, $\Delta G_{\text {cp }}$ is calculated at $1873 \mathrm{~K}$, which is the synthesis temperature used in this work. Even though $\Delta G_{\mathrm{cp}}$ cannot be estimated quantitatively for the intermixed structures, the contribution from configurational entropy to the free energy at elevated temperatures was estimated assuming a linear combination of the configurational entropy for the totally disordered structure and the semi/partially ordered structures. The dashed lines in Fig. 10 plot $\Delta \mathrm{G}_{\mathrm{cp}}$ over the entire order domain. Not surprisingly, entropy stabilizes the slightly disordered structures. A conclusion that is again generally consistent with the results shown in Table II.

Figure 11 plots the density of states (DOS) for type A $\mathrm{Mo}_{2} \mathrm{TiAlC}_{2}$. Non-bonding core states of $\mathrm{C} 2 \mathrm{~s}$ and $\mathrm{Al} 2 \mathrm{~s}$ are located at -13 to $-10.5 \mathrm{eV}$ and -8.8 to $-3 \mathrm{eV}$, respectively. Between -7 and $-3 \mathrm{eV}$ Mo $4 \mathrm{~d}$ and $\mathrm{C} 2 \mathrm{p}$ states form a hybridized bond and for Ti $3 \mathrm{~d}$ and $\mathrm{C} 2 \mathrm{p}$ states this forms between -7 and $-3.5 \mathrm{eV}$. The double peak just below $-3 \mathrm{eV}$ shows partial hybridization of Mo $4 \mathrm{~d}$ and $\mathrm{Al} 2 \mathrm{p}$ states. States from $-1.7 \mathrm{eV}$ up to the Fermi level $\left(E_{\mathrm{f}}\right)$ are dominated by the Mo
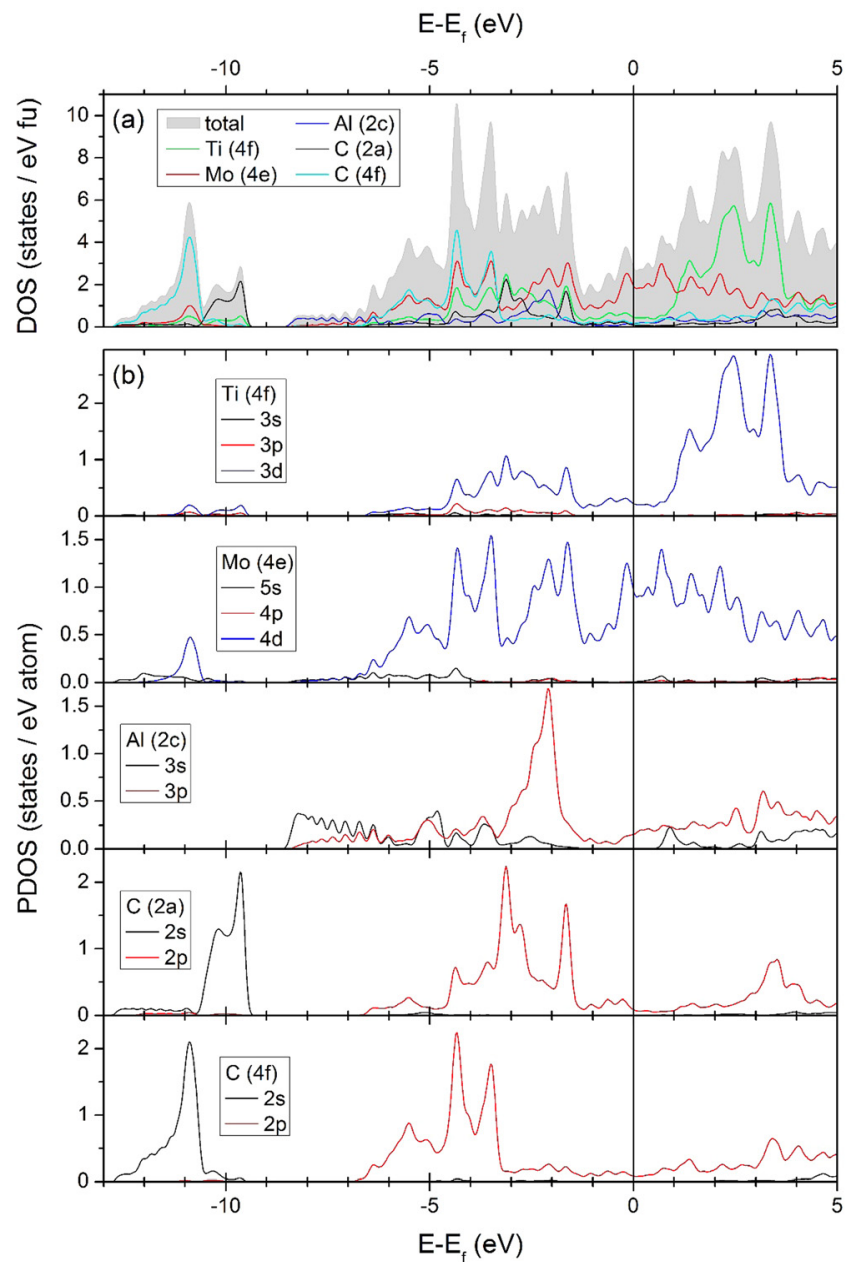

FIG. 12. Density of states (DOS) for type $\mathrm{A} \mathrm{Mo}_{2} \mathrm{Ti}_{2} \mathrm{AlC}_{3}$. (a) Total and atomic DOS and (b) partial DOS for each unique symmetry site. Vertical solid line indicates the location of the Fermi level $E_{f}$. 

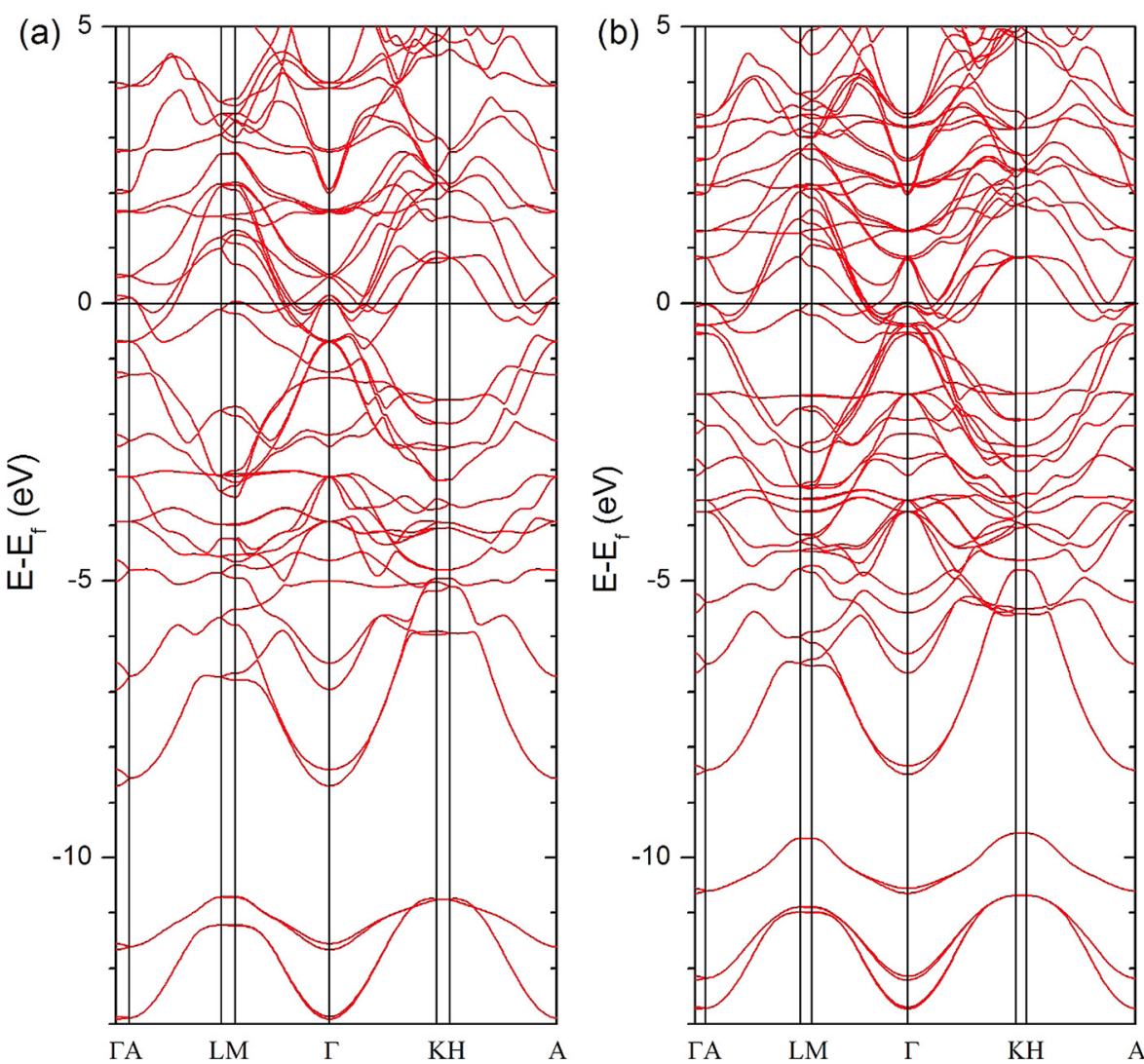

FIG. 13. Electronic band structure of type A, (a) $\mathrm{Mo}_{2} \mathrm{TiAlC}_{2}$ and (b) $\mathrm{Mo}_{2} \mathrm{Ti}_{2} \mathrm{AlC}$. Horizontal solid line at 0 represents the Fermi level $E_{f}$.

$4 d$ states that show no clear hybridization with other elements. The peak located just below $E_{\mathrm{f}}$ can mainly be attributed to Mo 4d states.

The DOS for type $\mathrm{A} \mathrm{Mo}_{2} \mathrm{Ti}_{2} \mathrm{AlC}_{3}$ is shown in Fig. 12 . Not surprisingly, they share many commonalities with Fig. 11. The major difference being the existence of two different C sites (2(a) and 4(f)), which results in a double peak of the non-bonding core states for $\mathrm{C} 2 \mathrm{~s}$ located at -12.8 to $-9.4 \mathrm{eV}$. The two sites also give rise to splitting of the $\mathrm{C} 2 \mathrm{p}$ peaks as they form hybridized bonds with both Mo $4 \mathrm{~d}$ and $\mathrm{Ti}$ $3 \mathrm{~d}$ between -7 and $-1.3 \mathrm{eV}$ and from -4.6 to $-1.3 \mathrm{eV}$. The states located close to $-2 \mathrm{eV}$ are due to partial hybridization of Mo $4 \mathrm{~d}$ and $\mathrm{Al} 2 \mathrm{p}$ states. From $-1.3 \mathrm{eV}$ to $E_{\mathrm{f}}$, the DOS is dominated by non-bonding Mo $4 \mathrm{~d}$ states. The latter are clearly dominant at $E_{\mathrm{f}}$.

Calculated electronic band structures of type A $\mathrm{Mo}_{2} \mathrm{TiAlC}_{2}$ and $\mathrm{Mo}_{2} \mathrm{Ti}_{2} \mathrm{AlC}_{3}$ along high-symmetry lines of the Brillouin zone are shown, respectively, in Figs. 13(a) and 13(b). Both show similar behavior, especially close to $E_{\mathrm{f}}$, which is dominated by the Mo $4 \mathrm{~d}$ states. Along with the DOS results shown in Figs. 11 and 12, it is reasonable to conclude that, like most other MAX phases, ${ }^{3}$ these compounds should be metallic conductors - as observed over most of the temperature range explored herein (Fig. 6) - mainly in-plane, with bands crossing $E_{\mathrm{f}}$ along various directions. The band structure also shows strong anisotropic features with less dispersion outof-plane, i.e., along the $c$-axis. Near $E_{\mathrm{f}}$ this anisotropy indicates that the conductivity should be larger in-plane as compared to out-of-plane.

The calculated elastic constants of type $\mathrm{A} \mathrm{Mo}_{2} \mathrm{TiAlC}_{2}$ and $\mathrm{Mo}_{2} \mathrm{Ti}_{2} \mathrm{AlC}_{3}$ and their end members are listed in Table VI. In both cases, the ordered quaternary compounds have higher moduli than their end members. This is most pronounced for $C_{44}$. Also the calculated $B_{\mathrm{v}}, G_{\mathrm{v}}$, and E moduli show improved values. For example, $+36 \%$ in $B_{\mathrm{v}}$ vs. $\mathrm{Ti}_{3} \mathrm{AlC}_{2}$, which may be correlated to the large decrease in unit cell volume $(-4.2 \%)$. As such, these ordered quaternary structures are not only highly stable, but they also seem to alter the

TABLE VI. Calculated elastic constants $C_{\mathrm{ij}}$, elastic moduli $B_{V}, G_{V}, E$, Poisson's ratio, $\nu$, anisotropy factor, $A$, and theoretical densities of $\mathrm{Ti}_{3} \mathrm{AlC}_{2}, \mathrm{Mo}_{3} \mathrm{AlC}_{2}$, $\mathrm{Mo}_{2} \mathrm{TiAlC}_{2}$ (type A) $\mathrm{Ti}_{4} \mathrm{AlC}_{3}, \mathrm{Mo}_{4} \mathrm{AlC}_{3}$, and $\mathrm{Mo}_{2} \mathrm{Ti}_{2} \mathrm{AlC}_{3}$ (type A).

\begin{tabular}{|c|c|c|c|c|c|c|c|c|c|c|c|}
\hline Phase & \multicolumn{8}{|c|}{$(\mathrm{GPa})$} & $\nu$ & A & $\rho\left(\mathrm{Mg} / \mathrm{m}^{3}\right)$ \\
\hline $\mathrm{Ti}_{3} \mathrm{AlC}_{2}$ & 357 & 79 & 76 & 290 & 119 & 163 & 127 & 302 & 0.19 & 0.96 & 4.21 \\
\hline $\mathrm{Mo}_{2} \mathrm{TiAlC}_{2}$-type $\mathrm{A}$ & 386 & 143 & 140 & 367 & 150 & 221 & 132 & 331 & 0.25 & 1.27 & 6.57 \\
\hline $\mathrm{Mo}_{3} \mathrm{AlC}_{2}$ & 354 & 143 & 149 & 352 & 110 & 216 & 106 & 274 & 0.29 & 1.08 & 7.43 \\
\hline $\mathrm{Ti}_{4} \mathrm{AlC}_{3}$ & 385 & 90 & 86 & 317 & 131 & 179 & 137 & 328 & 0.19 & 0.99 & 4.35 \\
\hline $\mathrm{Mo}_{2} \mathrm{Ti}_{2} \mathrm{AlC}_{3}$-type $\mathrm{A}$ & 424 & 130 & 144 & 382 & 163 & 230 & 149 & 367 & 0.23 & 1.26 & 6.20 \\
\hline $\mathrm{Mo}_{4} \mathrm{AlC}_{3}$ & 333 & 138 & 145 & 371 & 61 & 210 & 84 & 223 & 0.32 & 0.58 & 7.55 \\
\hline
\end{tabular}


bonding chemistry and thus improve the elastic properties with respect to their end members. The values predicted for $\mathrm{Mo}_{2} \mathrm{Ti}_{2} \mathrm{AlC}_{3}$ are noteworthily high: $\mathrm{C}_{11}$ is $>420 \mathrm{GPa}$ and $\mathrm{C}_{44}$ is $163 \mathrm{GPa}$.

The fact that these compounds are machinable with nothing more sophisticated that a manual hack saw, bodes well for their ultimate use in applications where high stiffness values, especially bulk moduli, are required with densities $\left(\approx 6 \mathrm{Mg} / \mathrm{m}^{3}\right)$ that are relatively low. Few other MAX phases have comparable elastic moduli. For example, the Ta-containing ones in general, and $\mathrm{Ta}_{4} \mathrm{AlC}_{3}$, in particular, ${ }^{57}$ have comparable values. The densities of the latter, however, are more than double those of $\mathrm{Mo}_{2} \mathrm{Ti}_{2} \mathrm{AlC}_{3}$.

Lastly, Liu et al. suggested that the high-order $\left(\mathrm{M}^{\prime}, \mathrm{M}^{\prime \prime}\right)_{3} \mathrm{AX}_{2}$ compounds form via insertion of $-\left(\mathrm{M}^{\prime} \mathrm{X}\right) \mathrm{m}-$ slabs into a $\mathrm{M}_{2} \mathrm{AX}$ structure. ${ }^{24}$ However, since $\mathrm{Mo}_{2} \mathrm{AlC}$ does not exist, this formation mechanism cannot be invoked here.

\section{SUMMARY AND CONCLUSIONS}

Herein, we showed that despite the fact that $\mathrm{Ti}_{3} \mathrm{AlC}_{2}$ is stable and $\mathrm{Mo}_{3} \mathrm{AlC}_{2}$ is far from being stable, the quaternary $\mathrm{Mo}_{2} \mathrm{TiAlC}_{2}$ is quite stable. Consistent with the experimental results presented in this and previous work, ${ }^{27}$ its lowest energy configuration is when it is ordered, with the Molayers sandwiching both the $\mathrm{Al}$ and Ti-C layers. The $a$ lattice parameter of the quaternary is lower than its end members. The opposite is true for the $c$ lattice parameters. The unit cell volume of the quaternary is lower than its end members.

Similarly, and despite the fact the $\mathrm{Ti}_{4} \mathrm{AlC}_{3}$ is at the verge of being stable and $\mathrm{Mo}_{4} \mathrm{AlC}_{3}$ is far from being stable, the quaternary $\mathrm{Mo}_{2} \mathrm{Ti}_{2} \mathrm{AlC}_{3}$ is stable. Like its 312 counterpart, its lowest energy configuration occurs when it is ordered, with repeated Mo-Ti-Ti-Mo layering, again consistent with our experimental work.

Both $\mathrm{Mo}_{2} \mathrm{TiAlC}_{2}$ and $\mathrm{Mo}_{2} \mathrm{Ti}_{2} \mathrm{AlC}_{3}$ can have moderate intermixing (0 to 25 at. \%), as observed experimentally and confirmed by DFT calculations. Based on our Rietveld refinement results, the outer $M$ layers, which are richer in Mo, tolerate more intermixing than the inner M layers ( $\mathrm{Ti}$ rich layers). The latter was explained by the fact that Mo atoms avoid being surrounded by $\mathrm{C}$ atoms in a FCC arrangement. The leitmotif of this work, and the driving force for ordering, is the high energetic penalty paid by the system when the Mo atoms are surrounded by $\mathrm{C}$ atoms in a FCC arrangement, i.e., $M$ sites not adjacent to $\mathrm{Al}$ layers.

In the case of $\mathrm{Mo}_{2} \mathrm{TiAlC}_{2}$, the $\mathrm{B}, \mathrm{G}$, and $\mathrm{E}$ values are predicted to be 221, 132, and $331 \mathrm{GPa}$, respectively. For $\mathrm{Mo}_{2} \mathrm{Ti}_{2} \mathrm{AlC}_{3-\mathrm{x}}$ the $\mathrm{B}, \mathrm{G}$, and $\mathrm{E}$ values are predicted to be 230 , 149 , and $367 \mathrm{GPa}$, respectively. Like the vast majority of the MAX phases, the DOS at $\mathrm{E}_{\mathrm{f}}$ is substantial, dominated by the Mo 4d states and explains its metallic-like conductivity.

The chemical formulae of $\mathrm{Mo}_{2} \mathrm{TiAlC}_{2}$ and $\mathrm{Mo}_{2} \mathrm{Ti}_{2} \mathrm{AlC}_{3}$ obtained from the XPS analysis- $-\mathrm{Mo}_{2} \mathrm{TiAlC}_{1.7}$ and $\mathrm{Mo}_{2} \mathrm{Ti}_{1.9} \mathrm{Al}_{0.9} \mathrm{C}_{2.5}$ - are in good agreement with those deduced from EDS. The XPS analysis shows almost no influence of Mo on the binding energy of the Ti species, whereas the binding energies of the Mo species are closer to those of $\mathrm{Mo}_{2} \mathrm{C}$ than to Mo metal. $\mathrm{Mo}_{2} \mathrm{TiAlC}_{2}$ has only one $\mathrm{C}$ species in the $1 \mathrm{~s}$ carbon region at $242.5 \mathrm{eV}$, while $\mathrm{Mo}_{2} \mathrm{Ti}_{2} \mathrm{AlC}_{3}$ has two peaks, one of which is the same as that for $\mathrm{Mo}_{2} \mathrm{TiAlC}_{2}$, and the second corresponds to the $\mathrm{C}$ in the inner layers bonded to $\mathrm{Ti}$ atoms only at a binding energy of $242.1 \mathrm{eV}$. Their ratio is 2 to 1 consistent with the proposed structures and ordering.

Finally, we note that the importance of this work lies beyond the discovery of new ordered MAX phases, as exciting as that may be, but rather that the A-group element is $\mathrm{Al}$, that can be readily etched in HF. ${ }^{13}$ This in turn implies that Mo-based MXenes can now be fabricated and tested. This was accomplished ${ }^{28}$ and the results are encouraging.

\section{ACKNOWLEDGMENTS}

E.J.M. and S.J.M. were supported by the U.S. Army Research Office under Grant No. W911NF-12-1-0132. Acquisition of the PPMS was supported by the U.S. Army Research Office under Grant No. W911NF-11-1-0283. Further, we acknowledge support from the Swedish Research Council (Project Grant Nos. \#621-2011-4420, 642-2013-8020, and 621-2014-4890), the Swedish Foundation for Strategic Research through the Synergy Grant FUNCASE Functional Carbides for Advanced Surface Engineering (J.R., P.E., M.W.B., and J.H.), the Future Research Leaders 5 Program (P.E. and J.L.), and the ERC Grant agreement [No. 258509] (J.R.). The Knut and Alice Wallenberg Foundation is acknowledged for a Wallenberg Academy Fellowship (J.R.) and scholar (L.H.) and for supporting the Electron Microscopy Laboratory at Linköping University operated by the Thin Film Physics Division. Calculations were performed utilizing supercomputer resources supplied by the Swedish National Infrastructure for Computing (SNIC) at the PDC Center for High Performance Computing and National Supercomputer Centre.

${ }^{1}$ M. W. Barsoum and M. Radovic, Annu. Rev. Mater. Res. 41, 195 (2011). ${ }^{2}$ P. Eklund, M. Beckers, U. Jansson, H. Högberg, and L. Hultman, Thin Solid Films 518, 1851 (2010).

${ }^{3}$ M. W. Barsoum, MAX Phases: Properties of Machinable Ternary Carbides and Nitrides (John Wiley \& Sons, 2013).

${ }^{4}$ M. W. Barsoum and T. ElRaghy, J. Am. Ceram. Soc. 79, 1953 (1996)

${ }^{5}$ M. W. Barsoum, D. Brodkin, and T. ElRaghy, Scr. Mater. 36, 535 (1997).

${ }^{6} \mathrm{M}$. W. Barsoum, in Encyclopedia of Materials Science and Technology, edited by K. H. J. Buschow, R. W. Cahn, M. C. Flemings, E. J. Kramer, S. Mahajan, and P. Veyssiere (Elsevier, Amsterdam, 2006).

${ }^{7}$ M. Sundberg, G. Malmqvist, A. Magnusson, and T. El-Raghy, Ceram. Int. 30, 1899 (2004).

${ }^{8}$ X. H. Wang and Y. C. Zhou, Oxid. Met. 59, 303 (2003).

${ }^{9}$ D. J. Tallman, B. Anasori, and M. W. Barsoum, Mater. Res. Lett. 1, 115 (2013).

${ }^{10}$ G. M. Song, Y. T. Pei, W. G. Sloof, S. B. Li, J. T. M. De Hosson, and S. van der Zwaag, Scr. Mater. 58, 13 (2008).

${ }^{11}$ H. Yang, Y. Pei, J. Rao, and J. T. M. De Hosson, J. Mater. Chem. 22, 8304 (2012).

${ }^{12}$ A.-S. Farle, C. Kwakernaak, S. van der Zwaag, and W. G. Sloof, J. Eur. Ceram. Soc. 35, 37 (2015).

${ }^{13}$ M. Naguib, V. N. Mochalin, M. W. Barsoum, and Y. Gogotsi, Adv. Mater. 26, 982 (2014).

${ }^{14}$ J. Halim, M. R. Lukatskaya, K. M. Cook, J. Lu, C. R. Smith, L.-Å. Näslund, S. J. May, L. Hultman, Y. Gogotsi, P. Eklund, and M. W. Barsoum, Chem. Mater. 26, 2374 (2014).

${ }^{15}$ M. Ghidiu, M. R. Lukatskaya, M.-Q. Zhao, Y. Gogotsi, and M. W. Barsoum, Nature 516, 78 (2014). 
${ }^{16}$ L. E. Toth, J. Less Common Met. 13, 129 (1967).

${ }^{17}$ R. Meshkian, A. S. Ingason, M. Dahlqvist, A. Petruhins, U. B. Arnalds, F. Magnus, J. Lu, and J. Rosen, Phys. Status Solidi RRL 9, 197 (2015).

${ }^{18}$ C. Hu, C. Li, J. Halim, S. Kota, D. J. Tallman, and M. W. Barsoum, J. Am. Ceram. Soc. (published online).

${ }^{19}$ C. Hu, C.-C. Lai, Q. Z. Tao, J. Lu, J. Halim, L. Sun, J. Zhang, J. Yang, B. Anasori, J. Wang, Y. Sakka, L. Hultman, P. Eklund, J. Rosen, and M. W. Barsoum, Chem. Commun. 51, 6560 (2015).

${ }^{20}$ M. Naguib, G. Bentzel, J. Shah, J. Halim, E. Caspi, J. Lu, L. Hultman, and M. Barsoum, Mater. Res. Lett. 2, 233-240 (2014).

${ }^{21}$ H. Nowotny, P. Rogl, and J. C. Schuster, J. Solid State Chem. 44, 126 (1982).

${ }^{22}$ A. Mockute, J. Lu, E. J. Moon, M. Yan, B. Anasori, S. J. May, M. W. Barsoum, and J. Rosen, Mater. Res. Lett. 3, 16-22 (2015).

${ }^{23}$ A. Mockute, M. Dahlqvist, J. Emmerlich, L. Hultman, J. Schneider, P. O. A. Persson, and J. Rosen, Phys. Rev. B 87, 094113 (2013).

${ }^{24}$ Z. Liu, E. Wu, J. Wang, Y. Qian, H. Xiang, X. Li, Q. Jin, G. Sun, X. Chen, J. Wang, and M. Li, Acta Mater. 73, 186 (2014).

${ }^{25}$ E. N. Caspi, P. Chartier, F. Porcher, F. Damay, and T. Cabioc'h, Mater. Res. Lett. 3, 100-106 (2015).

${ }^{26}$ W. Jeitschko and H. Nowotny, Monatsh. Chem. 98, 329 (1967).

${ }^{27}$ B. Anasori, J. Halim, J. Lu, C. A. Voigt, L. Hultman, and M. W. Barsoum, Scr. Mater. 101, 5 (2015).

${ }^{28}$ B. Anasori, Y. Xie, M. Beidaghi, J. Lu, B. C. Holser, L. Hultman, Y. Gogotsi, and M. Barsoum, ACS Nano (published online).

${ }^{29}$ H. M. Rietveld, J. Appl. Crystallogr. 2, 65 (1969).

${ }^{30}$ J. Rodríguez-Carvajal, Phys. B: Condens. Matter 192, 55 (1993).

${ }^{31}$ P. E. Blöchl, Phys. Rev. B 50, 17953 (1994).

${ }^{32}$ G. Kresse and J. Hafner, Phys. Rev. B 48, 13115 (1993).

${ }^{33}$ G. Kresse and D. Joubert, Phys. Rev. B 59, 1758 (1999).

${ }^{34}$ G. Kresse and J. Hafner, Phys. Rev. B 49, 14251 (1994).

${ }^{35}$ J. P. Perdew, K. Burke, and M. Ernzerhof, Phys. Rev. Lett. 77, 3865 (1996).

${ }^{36}$ H. J. Monkhorst and J. D. Pack, Phys. Rev. B 13, 5188 (1976).

${ }^{37}$ A. Zunger, S. H. Wei, L. G. Ferreira, and J. E. Bernard, Phys. Rev. Lett. 65, 353 (1990).

${ }^{38}$ M. Dahlqvist, B. Alling, I. A. Abrikosov, and J. Rosén, Phys. Rev. B 81, 024111 (2010).
${ }^{39}$ M. Dahlqvist, B. Alling, and J. Rosén, Phys. Rev. B 81, 220102 (2010).

${ }^{40}$ P. Eklund, M. Dahlqvist, O. Tengstrand, L. Hultman, J. Lu, N. Nedfors, U. Jansson, and J. Rosén, Phys. Rev. Lett. 109, 035502 (2012).

${ }^{41}$ A. S. Ingason, A. Mockute, M. Dahlqvist, F. Magnus, S. Olafsson, U. B. Arnalds, B. Alling, I. A. Abrikosov, B. Hjörvarsson, P. O. A. Persson, and J. Rosen, Phys. Rev. Lett. 110, 195502 (2013).

${ }^{42}$ A. S. Ingason, A. Petruhins, M. Dahlqvist, F. Magnus, A. Mockute, B. Alling, L. Hultman, I. A. Abrikosov, P. O. Å. Persson, and J. Rosen, Mater. Res. Lett. 2, 89 (2014)

${ }^{43}$ A. Petruhins, A. S. Ingason, J. Lu, F. Magnus, S. Olafsson, and J. Rosen, J. Mater. Sci. 50, 4495 (2015).

${ }^{44}$ A. Mockute, P. O. Å. Persson, F. Magnus, A. S. Ingason, S. Olafsson, L. Hultman, and J. Rosen, Phys. Status Solidi RRL 8, 420 (2014).

${ }^{45}$ L. Fast, J. M. Wills, B. Johansson, and O. Eriksson, Phys. Rev. B 51, 17431 (1995).

${ }^{46}$ See supplementary material at http://dx.doi.org/10.1063/1.4929640 for XRD Rietveld refinement and further resistivity, XPS and theoretical analysis.

${ }^{47}$ H. W. Hugosson, O. Eriksson, L. Nordström, U. Jansson, L. Fast, A. Delin, J. M. Wills, and B. Johansson, J. Appl. Phys. 86, 3758 (1999).

${ }^{48}$ M. W. Barsoum, L. Farber, I. Levin, A. Procopio, T. El-Raghy, and A. Berner, J. Am. Ceram. Soc. 82, 2545 (1999).

${ }^{49}$ L. Kiwi-Minsker and A. Renken, Catal. Today 110, 2 (2005).

${ }^{50}$ J. E. Krzanowski and R. E. Leuchtner, J. Am. Ceram. Soc. 80, 1277 (1997).

${ }^{51}$ J. Luthin and C. Linsmeier, Phys. Scr. 2001, 134 (2001).

${ }^{52}$ Y.-H. Chang and H.-T. Chiu, J. Mater. Res. 17, 2779 (2002).

${ }^{53}$ M. C. Biesinger, L. W. M. Lau, A. R. Gerson, and R. S. C. Smart, Appl. Surf. Sci. 257, 887 (2010)

${ }^{54}$ S. Myhra, J. A. A. Crossley, and M. W. Barsoum, J. Phys. Chem. Solids 62, 811 (2001).

${ }^{55}$ D. E. Mencer, Jr., T. R. Hess, T. Mebrahtu, D. L. Cocke, and D. G. Naugle, J. Vac. Sci. Technol. A 9, 1610 (1991).

${ }^{56}$ J. Etzkorn, M. Ade, and H. Hillebrecht, Inorg. Chem. 46, 7646 (2007).

${ }^{57}$ C. Hu, Z. Lin, L. He, Y. Bao, J. Wang, M. Li, and Y. Zhou, J. Am. Ceram. Soc. 90, 2542 (2007). 